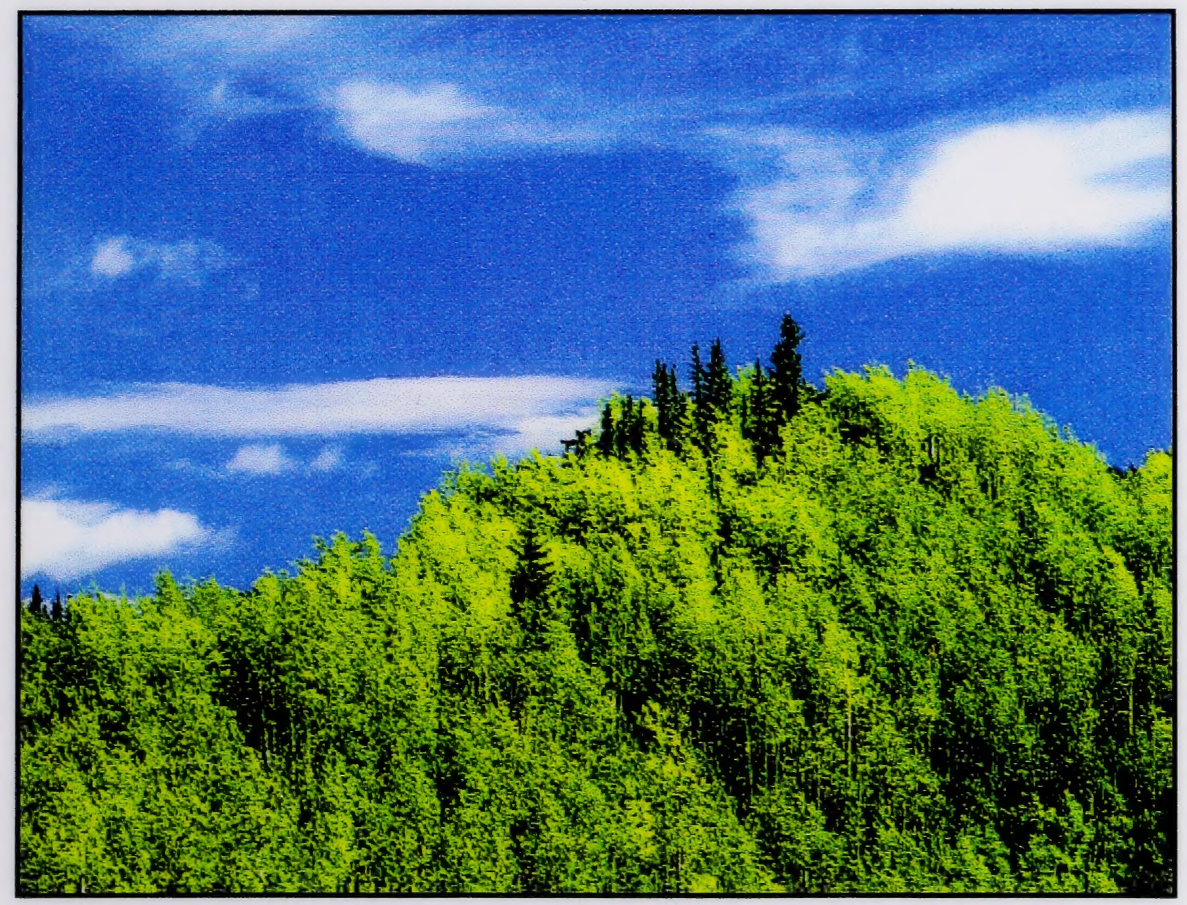

\title{
FOREST INDUSTRY SUPPLIERS SECTOR STUDY
}

Prepared by SENTAR Consultants Ltd. for:

Alberta Economic Development and Tourism and The Forest Industry Suppliers Association of Alberta

September 14, 1995
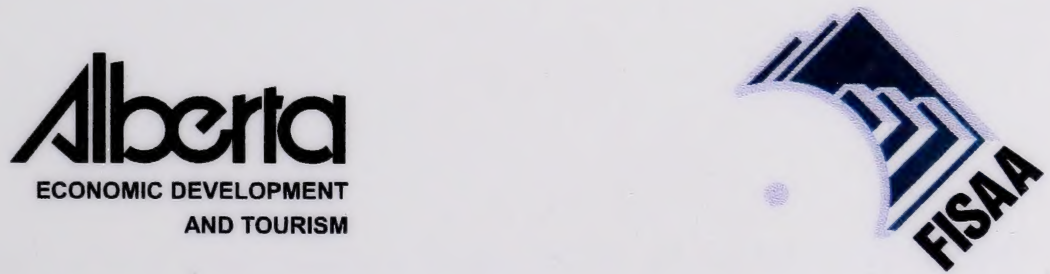
Digitized by the Internet Archive in 2015 
February, 1996

As Minister of Alberta Economic Development and Tourism, I am pleased to release the Alberta Forest Industry Suppliers Sector Study in cooperation with the Forest Industry Suppliers Association of Alberta.

This is the first study that has been undertaken to analyze the forest industry suppliers within Alberta, an important step in encouraging growth in this industry. The study has provided a profile of the industry and identified economic benefits from their activities together with market limitations and growth opportunities.

A joint steering committee with representatives from the Forest Industry Suppliers Association and Alberta Economic Development and Tourism was responsible for managing the study. I would like to express our appreciation to the 500 Alberta forest industry suppliers who participated in the study and provided valuable background information.

This study is an excellent example of the ongoing partnership arrangements between industry and the Alberta government in our endeavors towards identifying and promoting new opportunities as part of the Alberta Advantage.

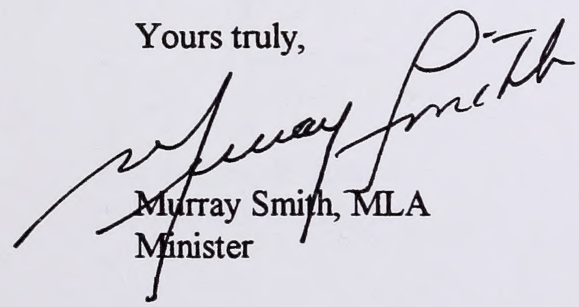





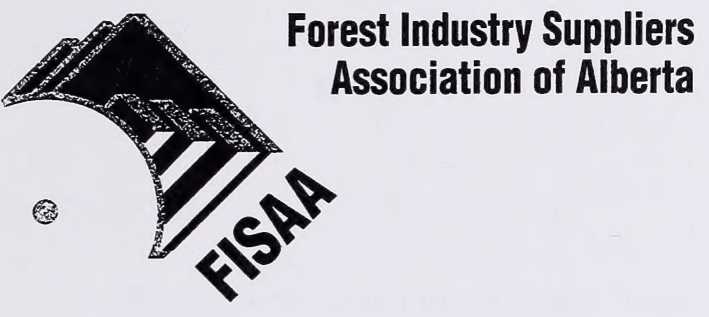

$510,10130-112$ Street

Edmonton, Alberta

T5K 2K4

Phone: (403) 426-7898

Fax: (403) $426-4778$

February, 1996

As President of the Forest Industry Suppliers Association, I am pleased to release the Alberta Forest Industry Suppliers Sector Study in cooperation with Alberta Economic Development and Tourism.

The Association is proud to be partners in this study that has been undertaken to analyze the forest industry suppliers within Alberta. The Association now has important information pertaining to the industry's profile and its current and potential impact on the Alberta economy.

Our thanks to the 500 Alberta forest industry suppliers who participated in the study and provided information that served as the background for the analysis. The study's recommendations will be of value to the Association's members and industry stakeholders.

I would like to express the Association's appreciation to Alberta Economic Development and Tourism for their support and we look forward to working cooperatively on the outcomes of this study.

Yours truly,

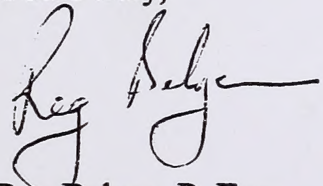

Reg Belyea, P. Eng.

President \& Chairman 


\section{DISCLAIMER}

The study on which this report is based was funded by the Forest Industry Development Branch of the Alberta Department of Economic Development and Tourism. The views, statements and conclusions expressed and the recommendations made in this report are entirely those of SENTAR Consultants Ltd. and should not be construed as the statements or conclusions of or as expressing the opinions of, either the branch, or the Department of Economic Development and Tourism.

Additional copies of this publication are available from:

Alberta Department of Economic Development and Tourism

Forest Industry Development Branch

13th Floor, Commerce Place

10155 - 102 Street

Edmonton, Alberta

T5J 4 L6

Telephone: (403) 427-6569; Fax: (403) 427-5299

Forest Industry Suppliers Association of Alberta

510, 10130 - 112 Street

Edmonton, Alberta

T5K 2K4

Telephone: (403) 426-7898; Fax: (403) 426-4778 


\section{ACKNOWLEDGMENTS}

SENTAR Consultants Ltd. wishes to thank the many individuals and organizations who provided valuable assistance and insight. The steering committee provided direction and advice through all stages of the project. In particular, Paul Short and Roly Ferris of Alberta Economic Development and Tourism, John Sandmoen of Alberta Power and Brent Rabik, past president of the Forest Industry Association of Alberta, offered their practical suggestions and critical reviews.

Information gathered from Alberta's forest industry suppliers forms the basis of this study. Special thanks go to the 155 companies who responded to the questionnaire. From this group, 25 attended a day-long workshop to expand on issues which were raised by respondents to the questionnaire. We are indebted to these companies and their representatives.

Others providing assistance included the Alberta Forest Products Association and its members and the Forest Industry Suppliers Association, notably Linda Ungarian.

The study was funded by Forest Industry Development Branch of Alberta Economic Development and Tourism. We are grateful to the staff of the Branch for their support and encouragement. 


\section{EXECUTIVE SUMMARY}

Suppliers to Alberta's forest industry have a significant impact on the province of Alberta's economy. The following table outlines a portion of the revenue generated by this economic sector, along with the number of employees.

Revenue and Employment - Alberta Forest Industry Supply Sector ${ }^{*}$

\begin{tabular}{|c|c|c|c|c|}
\hline & \multicolumn{2}{|c|}{ Alberta Sales Revenue } & \multicolumn{2}{|c|}{ Alberta Employees } \\
\hline & Total & Forest Industry & Total & Forest Industry \\
\hline FISAA Members. & $\$ 2.86$ billion & $\$ 255$ million & 14,979 & 2,097 \\
\hline $\begin{array}{l}\text { FISAA Members excluding } \\
\text { Power Companies }: ~\end{array}$ & $\$ 870$ million & $\$ 123$ million & 11,579 & 1,621 \\
\hline Non-FISAA Members & $\$ 232$ million & $\$ 67$ million & 1,752 & 456 \\
\hline
\end{tabular}

*These numbers reflect the responses of a maximum of 155 companies that provide supplies to the Alberta forest industry. This is a limited sampling of Alberta's forest industry supply sector.

The forest industry has been part of Alberta's economy since the early 1900s, and some companies surveyed in this study have supplied this industry for more than 45 years. Most suppliers, however, have only been active for 10 years or less. The growth in the supply sector reflects the expansion in Alberta's forest industry that occurred approximately 10 years ago.

While the forest industry is an important part of their business, for most suppliers it generates less than one-third of their annual revenue. Supplies to the oil and gas, and other sectors, account for most of the revenue of the firms surveyed in this study.

These two factors--the recent entry into forest industry supply and the percentage of revenue generated relative to other sectors--have led to some marketing challenges for the forest industry supply sector. 
The study survey and workshop gave suppliers an opportunity to discuss how they could develop their supply of materials and services to Alberta's forest industry. Overwhelmingly, respondents said that improved marketing would lead to higher sales.

In order to achieve this, suppliers said that they would have to develop a greater understanding of the technologies used in the forest industry. Suppliers who have an excellent knowledge of the oil and gas sector would also have to learn the "language" of the forest industry. Education, through the development of seminars or courses that would introduce suppliers to the forest industry, was seen as a way of bridging the gap of understanding with the forest industry.

Suppliers also recognized that they can do more, as a group and as individual firms, to gather intelligence on developments in the forest industry. At an individual level, suppliers must invest the time and energy to learn who the decision-makers are, and provide these individuals with the information they need to make purchasing decisions.

Markets outside of Alberta provide significant revenue for a few Alberta suppliers. Working with the Alberta government and through FISAA, suppliers should examine how Alberta firms have achieved success in outside markets and determine what growth opportunities exist, particularly in the United States.

Related to this, Alberta firms should examine how they can develop joint ventures with out-of-province or overseas suppliers to provide services to the Alberta forest industry. Potential for joint ventures is strongest in the area of forest industry equipment and machinery supply.

Economic forecasts, prepared annually or biannually, would provide suppliers with intelligence that would assist them in developing business plans and marketing programs. These forecasts could be undertaken by FISAA, with the assistance of the provincial government. 
The suppliers recognize that engineering firms play an important role in the purchasing decisions of Alberta forest industries. Alberta consulting engineers should continue to enhance their level of services to mills, and, in doing so, consider the capabilities of Alberta companies when making purchasing recommendations to the forest industry.

While marketing is ultimately the responsibility of the individual company, the supplers' association, FISAA, can provide opportunities to meet producers through reverse trade shows, mill tours and seminars between suppliers and producers. Forest industry suppliers must work through their association to develop programs that will enhance their marketing opportunities. 
ACKNOWLEDGMENTS

Page

EXECUTIVE SUMMARY

iv

TABLE OF CONTENTS

ix

LIST OF FIGURES AND TABLES

xi

1.0 INTRODUCTION

1.1 BACKGROUND

1

1.2 PURPOSE

1.3 REPORT ORGANIZATION

2.0 STUDY METHODOLOGY

2.1 MEANS OF GATHERING INFORMATION 3

2.1.1 Research 3

2.1.2 Survey 3

$\begin{array}{lll}2.1 .3 & \text { Workshop } & 6\end{array}$

2.1.4 Interviews with Primary Forest Industry Producers $\quad 7$

2.2 KEY ASSUMPTIONS AND LIMITATIONS

2.2.1 Key Assumptions $\quad 8$

$\begin{array}{lll}2.2 .2 & \text { Limitations } & 8\end{array}$

$\begin{array}{lll}3.0 & \text { STUDY RESULTS } & 11\end{array}$

$\begin{array}{lll}3.1 & 11\end{array}$

3.1.1 Forest Industry Suppliers Development Study, May $1990 \quad 11$

3.1.2 A Study of the Economic Importance of the Forest Sector in Alberta, $1994 \quad 12$

3.1.3 Review of the Economic Impact of the Forest Industry in Alberta, 1994

3.1.4 Marketing to the Pulp and Paper Seminar, 1989, 1993

$\begin{array}{ll}3.2 & \text { SURVEY } \\ & 14\end{array}$

$\begin{array}{lll}3.2 .1 & \text { Results } & 14\end{array}$

$\begin{array}{ll}\text { Supply Industry Characteristics } & 15\end{array}$

Supply Industry Issues (Survey Results) $\quad 28$

$\begin{array}{lll}3.3 & 33\end{array}$

3.3.1 Group A - Networking Opportunities 33 


\section{TABLE OF CONTENTS}

3.3.2 Group B - Knowledge of Client Base

3.3.3 Group C - The Alberta Advantage

35

3.3.4 Group D - Promotion/Exposure

36

3.3.5 Group E - Client/Supplier Education and Awareness

37

3.3.6 General Workshop Comments

39

39

4.0 LIMITATIONS AND GROWTH OPPORTUNITIES

41

4.1 SUPPLIER MARKETING

41

4.2 CLIENT PURCHASING

42

4.3 SUPPLIER QUALIFICATION AND EXPERIENCE 42

5.0 CONCLUSIONS AND RECOMMENDATIONS 45

$\begin{array}{lll}5.1 & 45\end{array}$

$\begin{array}{lll}5.2 & \text { FISAA } & 46\end{array}$

5.2.1 Reverse Trade Shows/Mill Plant Tours 46

$\begin{array}{lll}5.2 .2 & \text { Forest Industry Education } & 46\end{array}$

$\begin{array}{lll}5.2 .3 & \text { Resource Library } & 47\end{array}$

$\begin{array}{lll}\text { 5.2.4 Supplier On-line Database } & 47\end{array}$

5.2.5 Revise Annual FISAA Membership Survey $\quad 47$

5.2.6 Forest Industry Profile - Western Canada $\quad 47$

$\begin{array}{lll}5.3 & \text { PROVINCE OF ALBERTA } & 48\end{array}$

$\begin{array}{lll}\text { 5.3.1 Export Strategy } & 48\end{array}$

$\begin{array}{ll}\text { 5.3.2 Economic Forecasts } & 48\end{array}$

5.3.3 Alberta Engineering Content $\quad 49$

$\begin{array}{lll}5.4 & 50\end{array}$

\section{APPENDICES}

APPENDIX A: SURVEY QUESTIONNAIRE

APPENDIX B: LISTS OF SURVEY RESPONDENTS AND WORKSHOP PARTICIPANTS

APPENDIX C: "PARKING LOT" OF WORKSHOP POINTS REQUIRING FURTHER DISCUSSION APPENDIX D: DEFINITION OF CATEGORIES

APPENDIXE: BIBLIOGRAPHY 


\section{TABLE OF CONTENTS}

Page

\section{LIST OF FIGURES}

FIGURE 1: SURVEY DISTRIBUTION

FIGURE 2: $\quad$ SUPPLIES TO THE FOREST INDUSTRY - FISAA MEMBERS 15

FIGURE 3: SUPPLIES TO THE FOREST INDUSTRY - NON FISAA MEMBERS

FIGURE 4: NUMBER OF YEARS SUPPLYING ALBERTA'S FOREST INDUSTRY

- FISAA MEMBERS

FIGURE 5: NUMBER OF YEARS SUPPLYING ALBERTA'S FOREST INDUSTRY

- NON FISAA MEMBERS

FIGURE 6: NUMBER OF SERVICE OR PRODUCT CATEGORIES SUPPLIED

- FISAA MEMBERS

FIGURE 7: NUMBER OF SERVICE OR PRODUCT CATEGORIES SUPPLIED

- NON FISAA MEMBERS

FIGURE 8: FOREST SECTOR CUSTOMERS - FISAA MEMBERS

FIGURE 9: FOREST SECTOR CUSTOMERS - NON FISAA MEMBERS

FIGURE 10: GROSS REVENUE LAST YEAR FROM ALBERTA CUSTOMERS

- FISAA MEMBERS

FIGURE 11: GROSS REVENUE LAST YEAR FROM ALBERTA CUSTOMERS

- NON FISAA MEMBERS

FIGURE 12: REVENUE FROM FOREST INDUSTRY OUTSIDE OF ALBERTA

- FISAA MEMBERS

FIGURE 13: REVENUE FROM FOREST INDUSTRY OUTSIDE OF ALBERTA

- NON FISAA MEMBERS

FIGURE 14: GROSS REVENUE OF COMPANIES WITH HEAD OFFICES IN ALBERTA

- FISAA MEMBERS

FIGURE 15: GROSS REVENUE OF COMPANIES WITH HEAD OFFICES IN ALBERTA

- NON FISAA MEMBERS

FIGURE 16: REVENUE FROM FOREST INDUSTRY SOURCES OUTSIDE OF ALBERTA WITH HEAD OFFICES IN ALBERTA - FISAA MEMBERS

FIGURE 17: REVENUE FROM FOREST INDUSTRY SOURCES OUTSIDE OF ALBERTA WITH HEAD OFFICES IN ALBERTA - NON FISAA MEMBERS 


\section{TABLE OF CONTENTS}

Page

FIGURE 18: EMPLOYEES IN ALBERTA - FISAA MEMBERS

23

FIGURE 19: EMPLOYEES IN ALBERTA - NON FISAA MEMBERS

23

FIGURE 20: TOTAL ALBERTA EMPLOYEES - FISAA MEMBERS

24

FIGURE 21: TOTAL ALBERTA EMPLOYEES - NON FISAA MEMBERS

24

FIGURE 22: HEAD OFFICE LOCATION - FISAA MEMBERS 25

FIGURE 23: HEAD OFFICE LOCATION - NON FISAA MEMBERS 25

FIGURE 24: REGIONAL OFFICES IN ALBERTA - FISAA MEMBERS 26

FIGURE 25: REGIONAL OFFICES IN ALBERTA - NON FISAA MEMBERS 26

FIGURE 26: FUTURE SUPPLY SECTORS MOVING INTO WITHIN 5 YEARS

- FISAA MEMBERS

FIGURE 27: FUTURE SUPPLY SECTORS MOVING INTO WITHIN 5 YEARS

- NON FISAA MEMBERS 28

FIGURE 28: $\quad$ LIMITING FACTORS - FISAA MEMBERS 29

FIGURE 29: $\quad$ LIMITING FACTORS - NON FISAA MEMBERS 29

FIGURE 30: $\quad$ MEASURES TO PROMOTE GROWTH - FISAA MEMBERS 30

FIGURE 31: $\quad$ MEASURES TO PROMOTE GROWTH - NON FISAA MEMBERS 30

FIGURE 32: $\quad$ ECONOMIC IMPROVEMENT OPPORTUNITIES - FISAA MEMBERS 31

FIGURE 33: ECONOMIC IMPROVEMENT OPPORTUNITIES - NON FISAA MEMBERS 31

FIGURE 34: $\quad$ SUPPLIER MARKETING ISSUES - FISAA MEMBERS 32

FIGURE 35: $\quad$ SUPPLIER MARKETING ISSUES - NON FISAA MEMBERS 32

\section{LIST OF TABLES}

TABLE 1: $\quad$ REVENUE AND EMPLOYMENT IN ALBERTA

TABLE 2: IMPLEMENTATION STEPS 


\subsection{INTRODUCTION}

\subsection{BACKGROUND}

The forest products industry in Alberta has grown significantly in the past decade. As this industry has grown, so too has the sector that supplies materials and services to Alberta's pulp and paper mills, lumber and panel board mills, woodlands operations and secondary forest products industries.

A large body of work exists to describe the forest products industry in Alberta. Less clearly understood, however, is the sector that serves the forest products industry. In order to further the development of their industry, suppliers chartered an association called the Forest Industry Suppliers Association of Alberta (FISAA) in 1990. The association has worked closely with Alberta Economic Development and Tourism (AED\&T) to enhance the business opportunities for its members. As part of this process, FISAA and AED\&T commissioned SENTAR Consultants Ltd. to conduct a study of the forest industry supply sector. This report represents the findings of that study.

\subsection{PURPOSE}

The purpose of this study is to analyze forest industry suppliers within Alberta, identifying the industry profile, economic benefits resulting from their activity, together with market limitations and growth opportunities.

Previous studies (IMC, 1990; Ernst and Young, 1994; Price Waterhouse, 1994) have characterized the suppliers' industry largely from the perspective of the primary producers. This study is the first to identify the supply industry from the viewpoint of the suppliers themselves. 
This study had six primary objectives, which are described as follows:

- Examine the corporate profile of the FISAA membership and identify where services are provided (e.g. solid wood, woodlands, pulp and paper);

- Distinguish between the different types of services which suppliers to the forest industry provide;

- Determine the economic value of the forest industry component to the individual company;

- Identify areas of development and opportunities for growth within the supply sector;

- Identify limitations which prevent the supply sector from achieving these opportunities; and

- $\quad$ Provide recommendations to overcome the limitations.

Recognizing that Alberta suppliers provide services to both Alberta-based forest industries and those outside of Alberta, the study also examined supply activity outside of Alberta.

\subsection{REPORT ORGANIZATION}

This report is organized into three sections:

- The first part, Sections 1 and 2, outline the study objectives and methodology, describing the work program and steps for gathering information.

- The second part, Section 3, provides results from the information gathering process. Quantitative information that profiles the industry is provided first, followed by qualitative information obtained from the survey and workshop.

- The third and final part, located in Sections 4 and 5, draws conclusions from the information and provides recommendations on actions to enhance the supply sector. 


\subsection{STUDY METHODOLOGY}

In order to gain a comprehensive overview of the forest industry supply sector, the study team developed four steps for gathering information. These were:

- Research from similar studies in Alberta and other jurisdictions;

- Design and administration of a survey questionnaire;

- $\quad$ Conducting a one-day workshop with survey participants; and

- Interviews with primary forest industry producers.

These four steps formed the basis for the study's conclusions and recommendations.

\subsection{MEANS OF GATHERING INFORMATION}

\subsubsection{Research}

The study team conducted a search for studies that would provide background information as well as models that would address market opportunities and limitations. The intent of the research was to build on the body of research that exists on Alberta's forest industry suppliers and to identify useful models from other jurisdictions or industries.

The second research track examined how other economic sectors have approached the issues of market opportunities and limitations, while the third form of research involved a search for studies of the forest supply sector in other jurisdictions, both in Canada and internationally

\subsubsection{Survey}

The design and administration of a survey questionnaire were important early steps in the study. By asking the appropriate questions, the survey could meet many of the study objectives. Basic information on corporate structure, number of employees, service types and revenue would develop a profile of the industry, while open-ended questions would identify areas requiring further discussion at the workshop. 
In developing a list of forest industry suppliers, the initial focus was the supplier's association, FISAA. This group, comprising 281 members, provided a base from which the industry would be characterized and issues of market limitations and growth opportunities could be explored. FISAA members and their types of services, provided parameters on what constitutes a forest industry supplier. From the FISAA membership list, 19 members or associate members were removed from the study sample, including 10 primary forest products companies, five associate members and four government agencies.

The adjusted FISAA membership list of 262 was augmented by other companies that were not members of FISAA, but had a high likelihood of providing services to the forest industry (designated as "non FISAA" members in the study). In total, 238 non FISAA companies were selected from Edmonton, Calgary and forest centres throughout Alberta to bring the list of survey recipients to 500 .

Non FISAA members were identified from many sources including:

- Pulp and Paper Canada 1994 Annual and Directory;

- $\quad$ FISAA's former members;

- The Alberta Forestry Directory: 1994-1995 Edition;

- Alberta Yellow Pages directories -- forestry, logging and machine categories in known forestry centres;

- A list of companies attending the Grande Prairie Forest Industry Trade Show;

- $\quad$ Alberta Economic Development and Tourism's Industrial Benefits Strategy database of forest industry suppliers;

- $\quad$ Suppliers to members of the Wood Manufacturing Council of Alberta;

- $\quad$ Trucking firms identified by K. Mak, ProForMa Forestry Consultants; and

- $\quad$ Additional firms identified by K. Mak, ProForMa Forestry Consultants.

The survey form was organized into five sections covering general corporate information, supplies to the forest industry, economic opportunities, financial information and workshop information. 
Part one of the survey asked for information on the number of employees in Alberta. This question was followed by a request for information on head office location regional office locations, as well as number of years supplying Alberta's forest industry.

The second part asked suppliers to list the type or types of services they provide to the forest industry. Services types where categorized according to a grouping of Statistics Canada SIC codes that relate to the forest supply industry.

The open-ended questions formed the third part of the survey. In this section, suppliers provided information on the limitations and economic opportunities in their industry. Issues identified in this section were used to design the workshop, structure forest industry interviews and provide a format to the report.

Financial information formed the fourth part of the survey. Responders were asked to distinguish the Alberta component of their gross revenue and identify the percentage of out-of-province forest industry revenue. This section also asked suppliers to identify their customer profile. Part five of the survey introduced the concept of a workshop and permitted responders to indicate whether they wished to attend.

The three-page survey form was intended to be concise in its presentation. Where possible, responses were as check marks or a single word or number. In order to obtain authoritative responses, all surveys were addressed to the owner, chief executive officer or manager of the company. The survey is attached in Appendix A.

More than two-thirds of the surveys were distributed by fax machine (351), while the remainder were mailed out (149). A three-week response time was granted for returning the survey, with two weekly faxed reminders and one mailed reminder. In the final week, 160 potential respondents were contacted by telephone as a reminder to return their survey forms. From the non FISAA members who were mailed questions, 18 did not reach their destination and were returned unopened. As a result the non FISAA sample size was reduced from 138 to 120 , and the overall sample from 500 to 482 . 
At the conclusion of the response period, 103 FISAA members returned their surveys, for a 39 per cent return rate, while 52 non FISAA members responded, or 24 per cent of the adjusted sample. Figure 1 outlines the returns during the four-week duration of the survey. Survey respondents are listed in Appendix B.

Figure 1

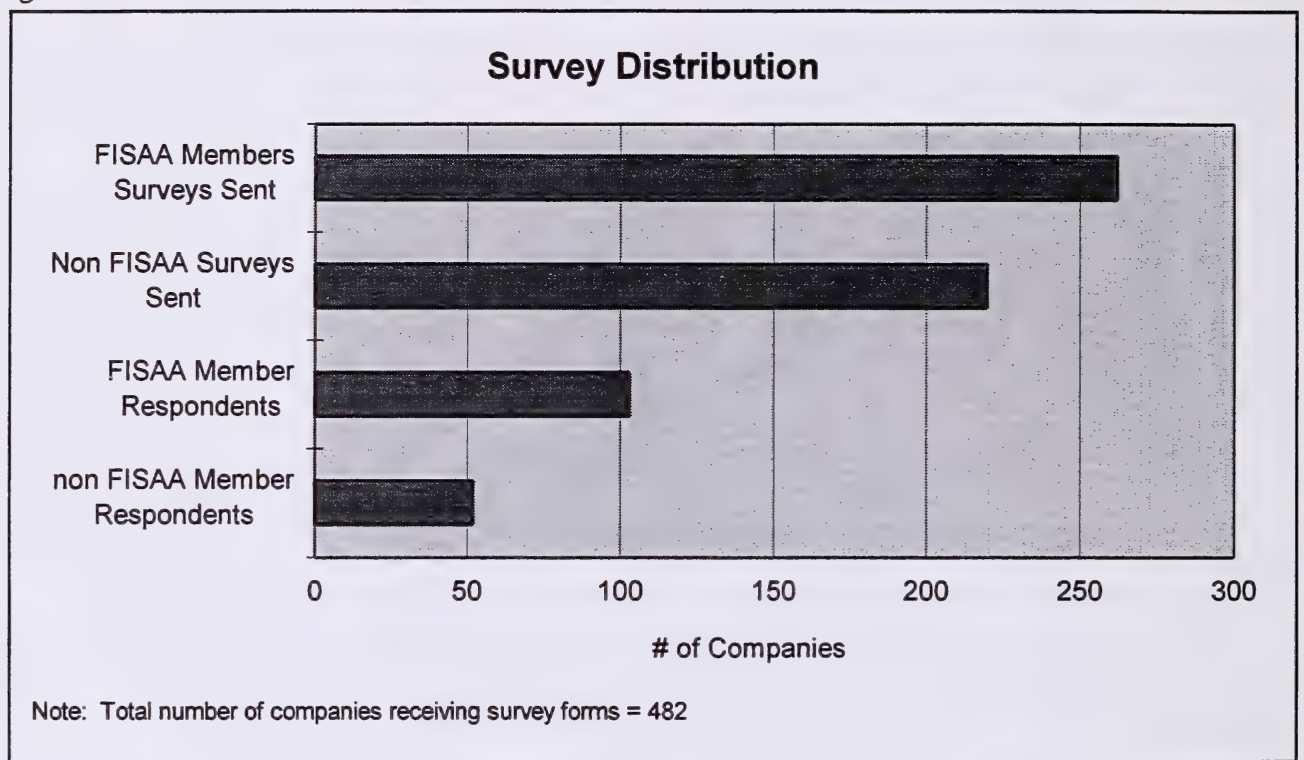

\subsubsection{Workshop}

Another component of the study was a one-day workshop with forest industry suppliers. This workshop provided an opportunity for all participants to understand issues of market limitations, growth opportunities and actions to enhance markets.

The survey responses to the open-ended questions (questions $3 \mathrm{a}, 3 \mathrm{~b}$ and $3 \mathrm{~d}$ ) formed the basis for the workshop. Responses were grouped in order of frequency and those most commonly mentioned became the discussion topics at the workshop. The workshop was intended for both FISAA and non FISAA members.

On the final section of the survey, recipients were asked whether they wished to participate in a workshop as part of the study. Due to a strong positive response to this question, the 
study team selected a limited number of potential workshop attendees. From 55 workshop invitations distributed, 25 individuals confirmed their attendance for the workshop on July $27,1995$.

At the workshop, the 25 participants were randomly assigned to five groups. Once the discussion groups were formed, members of each group received a topic-specific set of discussion materials. Discussion topics were based on a further breakdown of the marketing issues identified in question 3.d (refer to Figures 34 and 35).

The groups addressed the issues of growth opportunities, limitations and actions in two break-out sessions. Following each break-out session, the groups reported back to the larger group.

\subsubsection{Interviews with Primary Forest Industry Producers}

Using the information collected from the survey and workshop, the study team conducted interviews with three segments of the primary forest industry: pulp and paper, solid wood and woodlands operators. Procurement and senior management officials were interviewed from companies in each industry type. The information collected from these interviews is considered to be background information to the views of the forest industry suppliers.

\subsection{KEY ASSUMPTIONS AND LIMITATIONS}

The definition of a "forest industry supplier" can include every company that sells a product or service to a forest industry producer. Developing an all-encompassing list of forest industry suppliers in Alberta would be an exhaustive task, with no guarantee that the list would be complete. The study team recognized from the outset that general limitations must be established on what constitutes a "supplier" to the forest industry. For example, the study team recognized that certain companies, such as those which sell feller bunchers and pulping chemicals, are obviously suppliers to the forest products industry. On the other hand, hoteliers, promotional supply companies and custodial service firms are less obviously suppliers to the forest products industry. The challenge was to identify Alberta companies that could be reasonably classified as forest industry suppliers. 
Recognizing this, the study team used the membership list of FISAA and the range of services these members provide as a starting point for defining a supplier to the forest industry.

Comments on the assumptions and limitations of the sample selection and on the study are described below.

\subsubsection{Key Assumptions}

An over-riding assumption was that the survey sample of 500 companies was a reasonable representation of the forest industry supply sector. From this list, a strong survey response would provide a charcoal sketch of the industry and offer direction on the focus and content.

A second assumption was that the open-ended or qualitative survey responses represented the issues of the entire supply sector. This section of the survey was the only part that could be reasonably be aggregated upwards to represent the views of the industry. The responders to the survey--owners, presidents and managers--also added validity to the qualitative responses.

\subsubsection{Limitations}

The study team recognized that the information collected has limitations, and caution must be used in analyzing and interpreting this information.

First, the sample for the survey does not include all suppliers to Alberta's forest industry. As a result, quantitative information (e.g., financial figures) collected from the survey cannot be aggregated upwards as representing a percentage of the supply sector in Alberta. Although the sample of FISAA members that received surveys does constitute a whole unit, quantitative information still cannot be aggregated upwards from this group. However, the information offered from FISAA members provided a floor or base of numbers from which to build a profile of the entire membership. These base numbers can be aggregated 
upwards in the future to profile the FISAA membership via a revised annual survey questionnaire.

A related limitation is the group of suppliers that chose to respond to the survey. The information gathered from this group must be viewed in the following manner:

- Quantitative data are representative of the respondents only; and

- Qualitative information represents a portion of the opinion of the supply industry only.

While the study team structured the workshop to obtain as wide a representation of opinion on the supply sector, the comments of the workshop attendees represent the opinions of this group only.

Any comparisons between the FISAA members and non FISAA members must be qualified. These comparisons are provided as information only, and conclusions drawn from the survey relate to the responders only, which are grouped as FISAA and non FISAA members. 


\subsection{STUDY RESULTS}

As described previously, the study team collected information through research, administration of a survey, a workshop and interviews with forest industry producers. The results of these processes are described in the following pages.

\subsection{LITERATURE REVIEW AND RESEARCH}

In its review, the study team found that previous analyses on Alberta's forest industry suppliers have either focused on the views of the primary producers on the supply sector or on the views of a broad spectrum of producers, suppliers, trade associations, government and others. Although the foci of these studies differ, this body of knowledge still provides useful insight into the supply sector. The following sections summarize these studies.

The second research track searched for studies of other major (non-forestry) supply industries in Alberta and Canada. While several economic sectors have produced marketing analyses, these cannot be directly compared to a study of the forest industry suppliers. Indeed, no organization compares to the Forest Industry Suppliers Association of Alberta in its mandate and status as a supplier to a single Alberta industry.

All research involved searches of on-line databases (PTS F\&S technology index, Trade and Industry Database ${ }^{\mathrm{TM}}$, SIMONS Database). One product of these searches was a publication that provides general information on marketing supplies and services to the forest industry sector (TAPPI Guide on Marketing to the Pulp and Paper Sector). This guide is described in section 3.1.4.

\subsubsection{Forest Industry Suppliers Development Study, May 1990}

This study, funded by Alberta Economic Development and Trade and completed by IMC Consulting Group Inc., analyzed development opportunities for suppliers to pulp and paper mills in British Columbia and Alberta. In the Alberta portion, the study focused on the opportunities that were emerging as a result of an expansion of the pulp and paper industry. The intent was to survey pulp and paper producers to obtain information that would be useful to suppliers. 
In its summary of the Alberta picture, the IMC report identified the types and locations of services that were supplied to the pulp and paper industry and the form of business relationships preferred by producers. The producers mentioned that training programs that familiarize suppliers with pulp and paper technology would enhance the market opportunities for these suppliers. The provincial government was viewed as the body that would provide this training to increase the knowledge of the pulp and paper industry in Alberta.

Significant to the development of supplier markets, the IMC study found that 27 per cent of total purchases among the seven mills surveyed were from out-of-province suppliers. Of this 27 per cent, 60 per cent of supplies and five per cent of services were purchased from non-Alberta sources.

The IMC study must be viewed in the context of the large capital investment in the pulp and paper industry that occurred in the late 1980s and early 1990s. Such investments place a greater emphasis on the construction portion of supply, and less on supply to ongoing operation and maintenance.

\subsubsection{A Study of the Economic Importance of the Forest Sector in Alberta, 1994}

The firm Ernst \& Young completed a study that examined the potential economic importance of the forest products industry to the suppliers to that industry. Sponsors of the study were Economic Development Edmonton and the Canada-Alberta Partnership Agreement in Forestry. The approach involved a survey of the forest products industry and interviews with representatives from trade associations, academia, government, the logging industry, mills, equipment manufacturers and suppliers.

Using a survey and interviews, Ernst \& Young profiled the forest products industry and discussed issues relating to the supply sector. In the latter section, several conclusions were drawn: 
- $\quad$ Suppliers require a greater understanding of the needs of the forest industry. The most successful suppliers have experience working within the forest industry: these suppliers "speak the same language" as the mill personnel.

- $\quad$ Forest industry buyers require quality products, competitive pricing, and strong service and support. Producers prefer to buy local or provincial services, but these services must meet the above criteria. Suppliers must be aware of new technology and processes that will help the producers. Through attention to their clients' needs, these suppliers will develop ongoing business relationships with the forest industry.

- The greatest opportunity for growth is in the area of supply of process equipment. Companies that may consider entering this market must carefully assess issues such as economies of scale, research and development costs and the requirements of technical expertise.

\subsubsection{Review of the Economic Impact of the Forest Industry in Alberta, 1994}

While the scope of this project, completed by Price Waterhouse, was broad, it still included a useful analysis of the supply sector. Commissioned by Alberta Economic Development and Tourism, the study identified many of the same issues as the Ernst \& Young analysis. The study also included reference to the growing supply markets for high technology and silviculture services. 


\subsubsection{Marketing to the Pulp and Paper Seminar, 1989, 1993}

This seminar and the notes that accompany it were sponsored by the Technical Association of the Pulp and Paper Industry (TAPPI), based in Atlanta, Georgia. The accompanying notes provide a step-by-step introduction into the technical operation of a pulp and paper mill (supported by the Handbook for Pulp and Paper Technologists by G.A. Smook) as well as a systematic approach to marketing supplies and materials to pulp and paper mills. Pulp and paper growth trends for North America are also presented in the TAPPI seminar.

The seminar has a strong section on marketing, covering marketing research, planning, buyers, channels, promotions and buying motivations. For example, the TAPPI seminar describes the different types of surveys that can be used as information-gathering tools-from the personal interview methods to telephone and mail surveys.

Written in a clear and straightforward manner, the notes to the TAPPI seminar are recommended as a reference for marketing services to the pulp and paper industry in North America.

Notes from the 1995 seminar are presently unavailable in a published format. However, the handbook and notes from the 1993 seminar are available and can be obtained by calling TAPPI in Atlanta at (404 461-1400).

\subsection{SURVEY}

\subsubsection{Results}

Information collected from this survey was arranged into display graphs and characterized as either responses from FISAA members or non FISAA members. The results of the survey, based on these responses, are shown in the following sections. 


\section{Supply Industry Characteristics}

\section{Supplies}

Alberta companies supply a range of services to the forest industry. Types differ significantly between the FISAA and non FISAA groups who responded (Figures 2 and 3). Both groups, however, listed manufacturing products as the leading supply category.

Figure 2

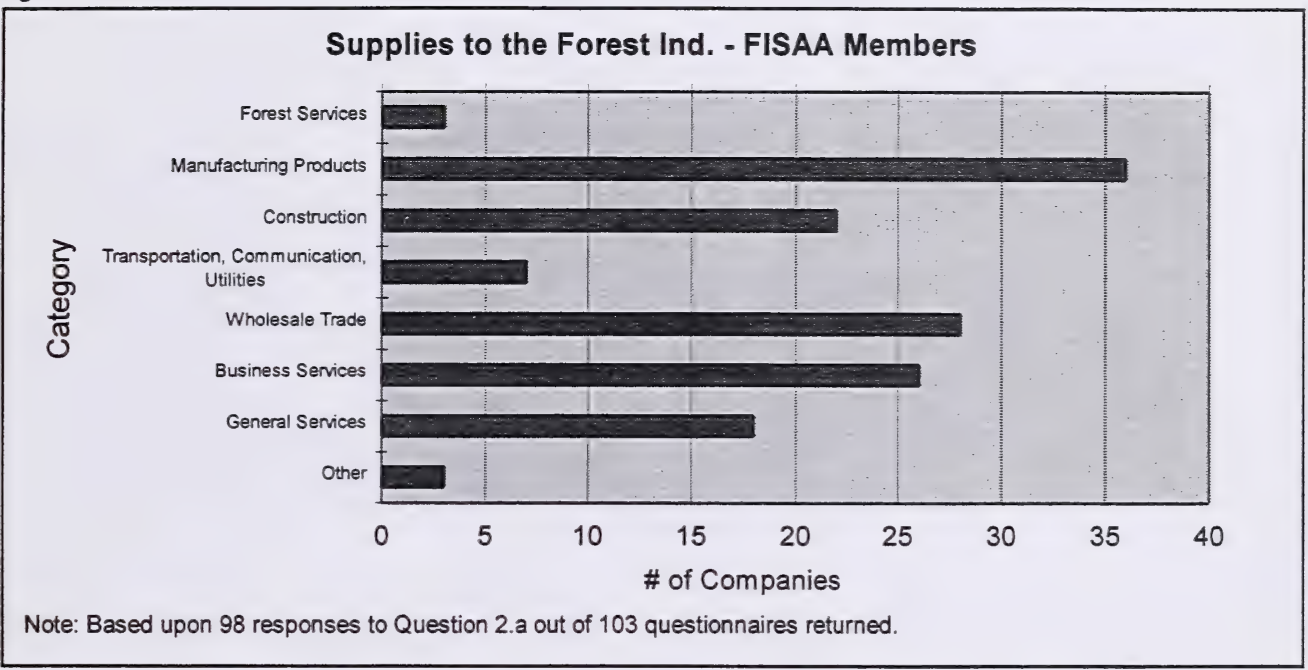

Figure 3

\section{Supplies to the Forest Ind. - Non FISAA Members}

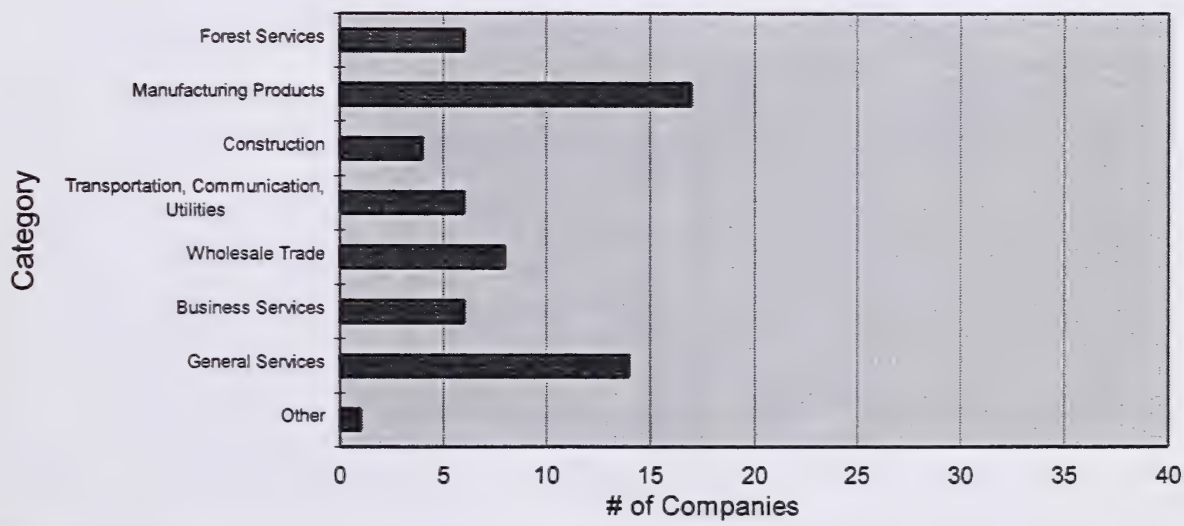

Note: Based upon 41 responses to Question 2.a out of 52 questionnaires returned. 
Number of Years in Forest Supply Business

Alberta's forest industry suppliers have been active for varying lengths of time. Among FISAA members, six to 10 years was the leading category of years of service, although the distribution was fairly even through the selected ranges. Non FISAA members listed five or fewer years as the leading category of service-years, although the distribution was fairly even up to 25 years (Figures 4 and 5).

Figure 4

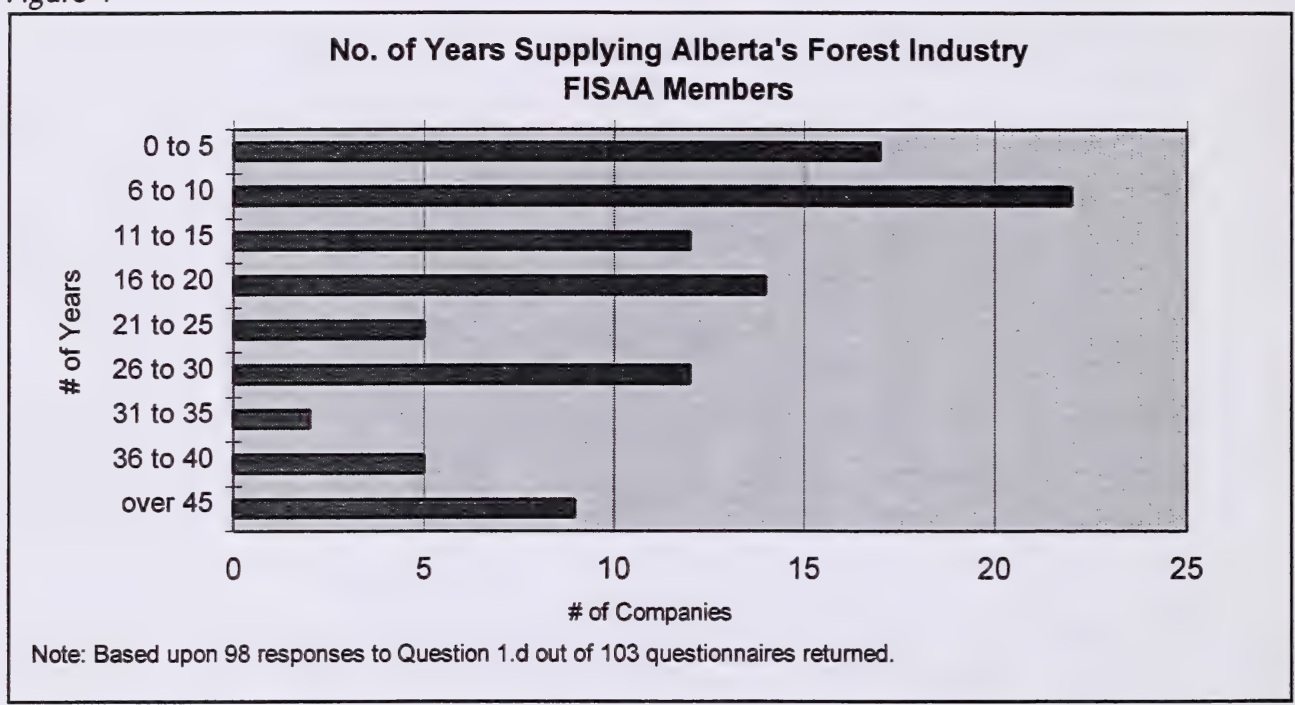

Figure 5

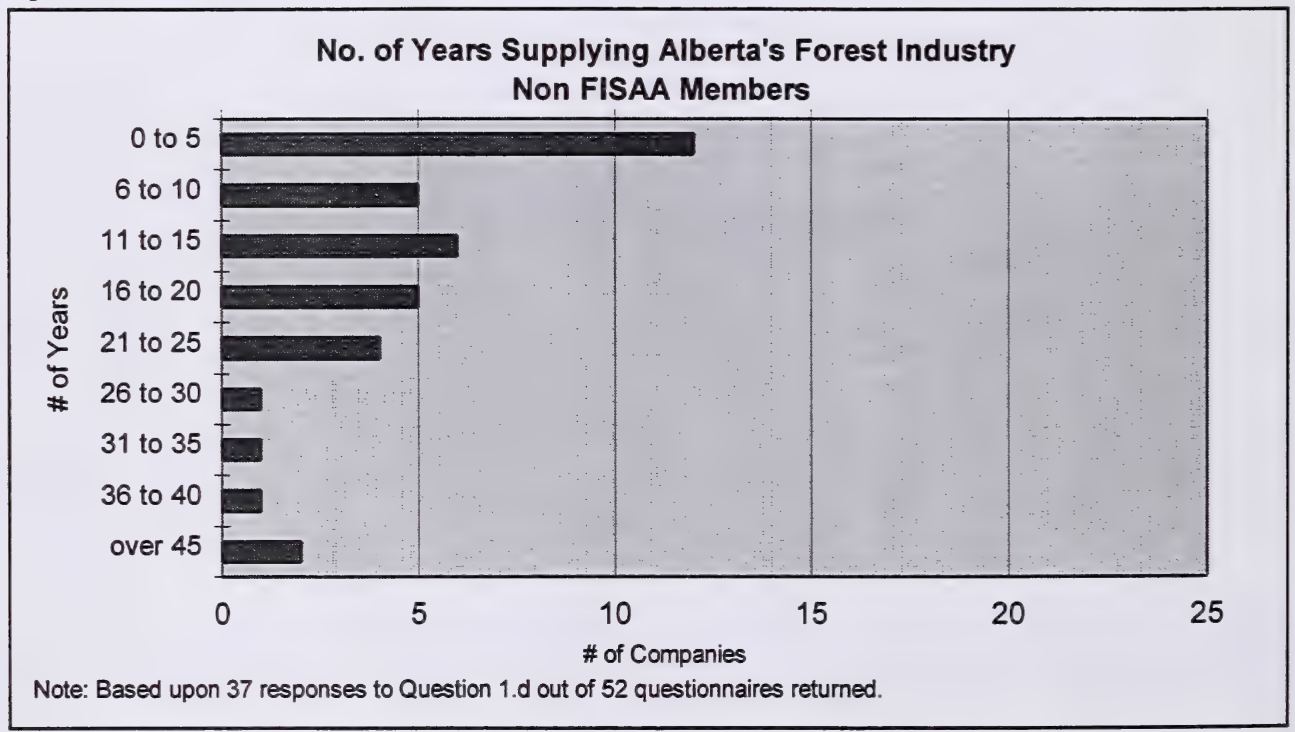


Supply Diversity

Responding companies generally provide only one type of service or product to the forest industry. This trend is more or less the same among FISAA members (Figure 6) and non FISAA members (Figure 7).

Figure 6

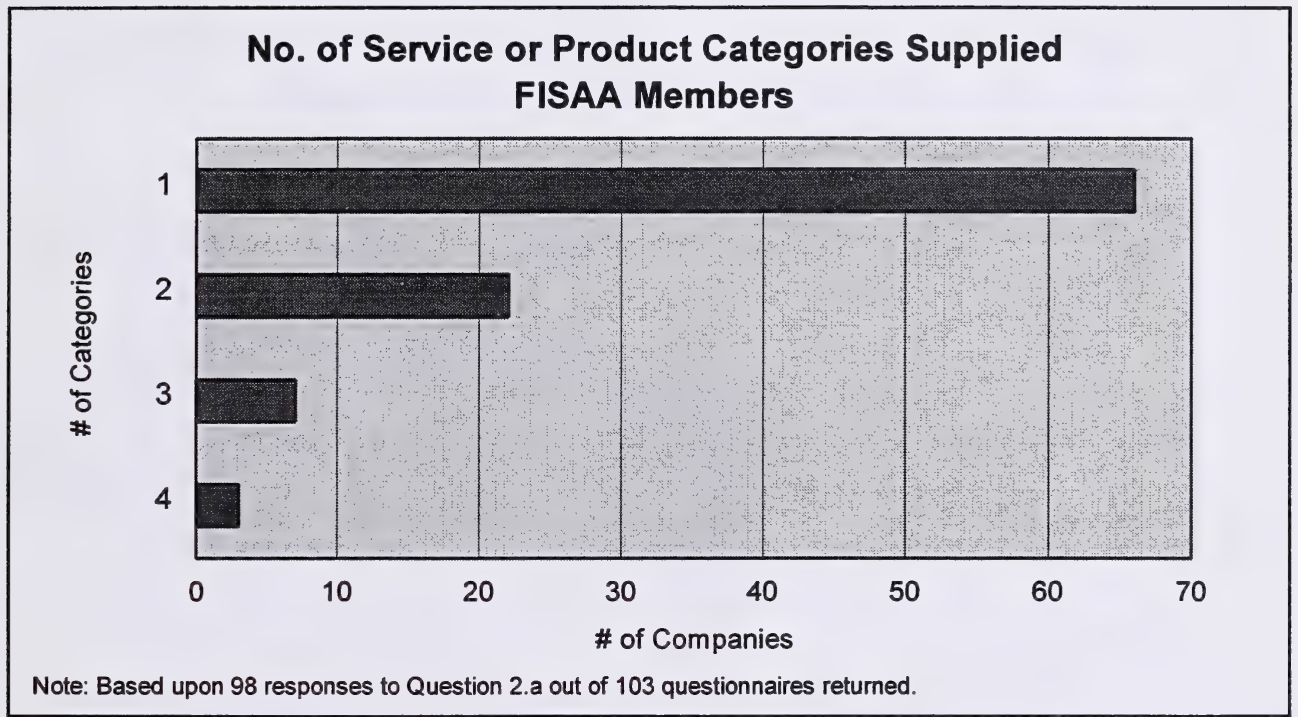

Figure 7

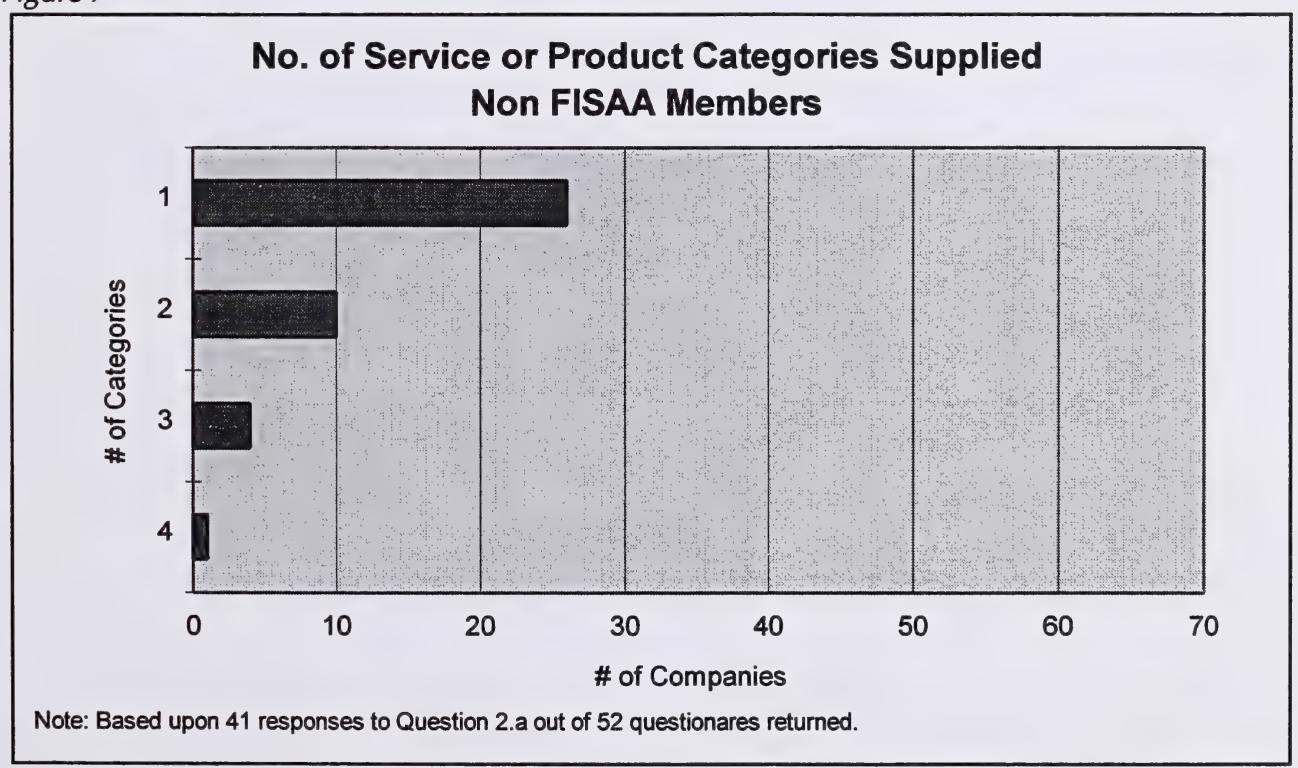




\section{Alberta Forest Customers}

In terms of customer types within the forest industry, 82 FISAA members supplied pulp and paper mills, more than any other category. The customer profile of non FISAA members was quite different, with 24 respondents listing logging and woodlands operations as the number one receiver of supplies (Figures 8 and 9).

Figure 8

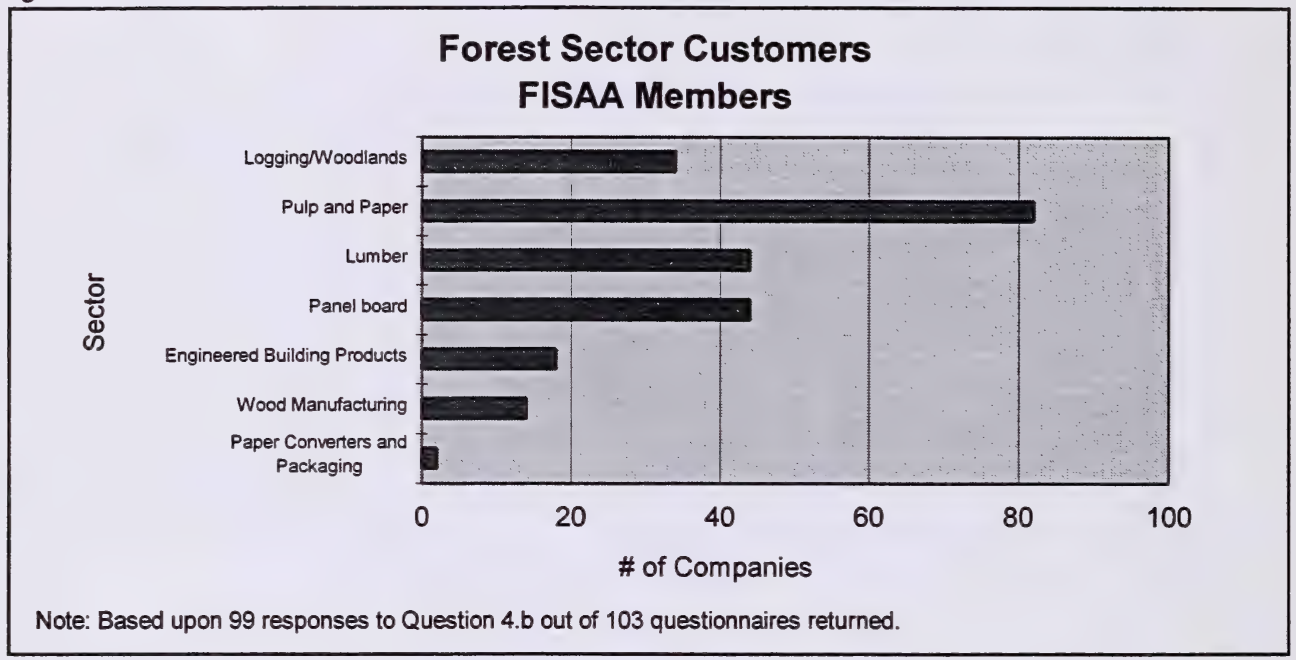

Figure 9

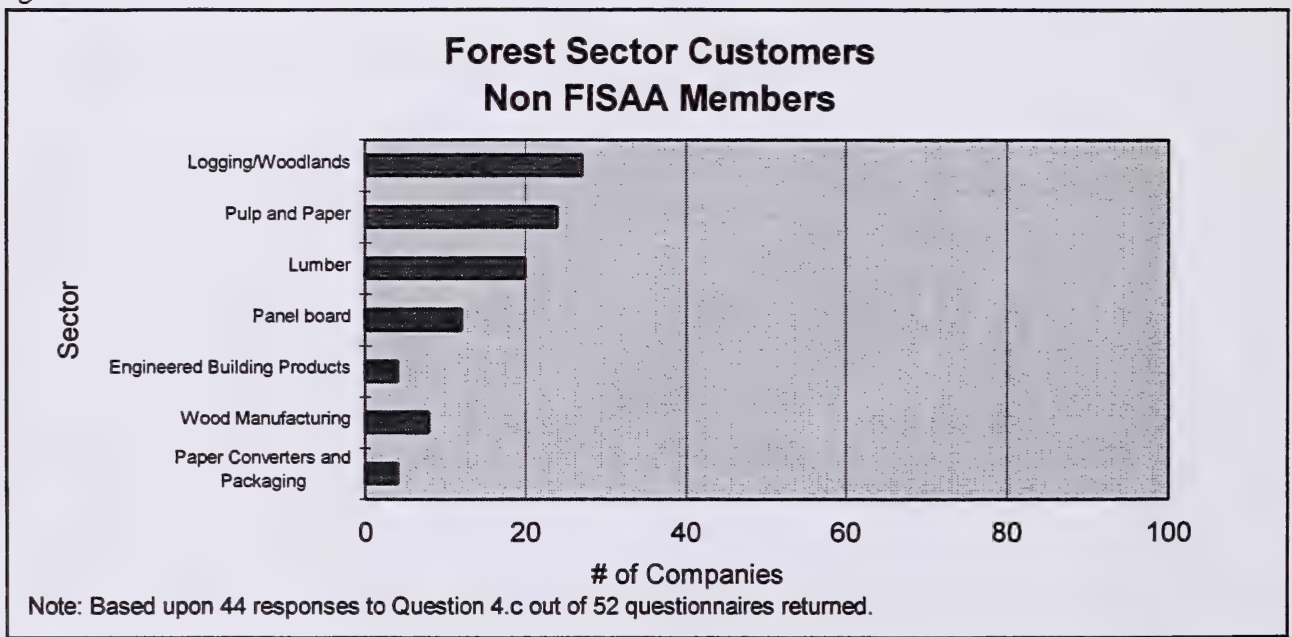




\section{Alberta Sales}

The survey showed that the forest industry accounted for nine per cent (FISAA members) and 29 per cent (non FISAA) of the suppliers' sales in Alberta (Figures 10 and 11). It should be noted that the survey results refer to 1994, which was a very active year for oil and gas development in Alberta. Thus, oil and gas industry revenue may be higher than in subsequent years.

Figure 10

\section{Gross Revenue Last Year From Alberta Customers FISAA Members}

Total Gross Revenue $=\$ 2.86$ billion

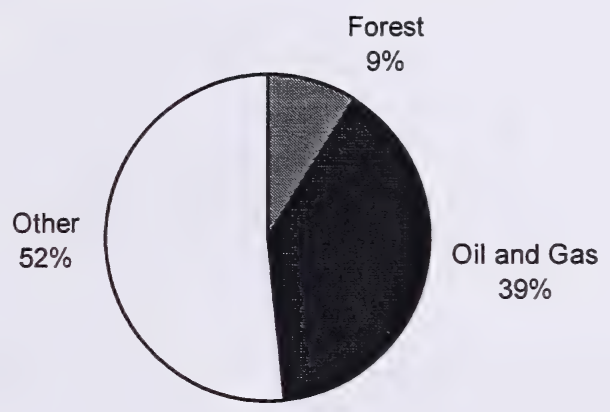

Note: Based upon 95 responses to Question 4.a.ii out of 103 questionnaires returned.

Figure 11

\section{Gross Revenue Last Year From Alberta Customers Non FISAA Members}

Total Gross Revenue $=\$ 232$ million

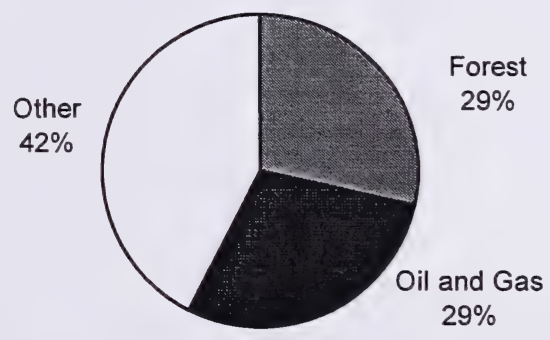

Note: Based upon 42 responses to Question 4.a.ii out of 52 questionnaires returned. 


\section{Forest Industry Sales Outside of Alberta}

Of revenue from forest industry sources outside of Alberta, British Columbia was greatest source for FISAA members (60 per cent), while "other provinces" was the largest export category for non-members, at 30 per cent (Figures 12 and 13).

Figure 12

\section{Revenue from Forest Industry Outside of Alberta \\ FISAA Members \\ Total revenue $=\$ 475$ million}

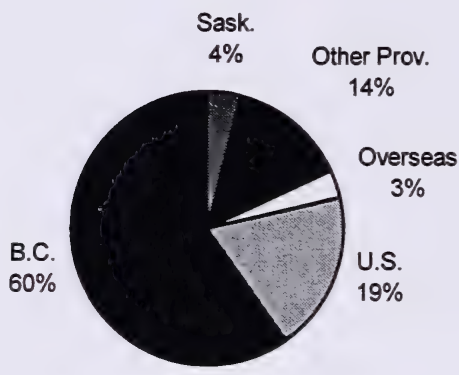

Note: Based on 40 responses to Question 4.c out of 103 questionnaires returned.

Figure 13

\section{Revenue from Forest Industry Outside of Alberta Non FISAA Members \\ Total revenue $=\$ 341$ million}

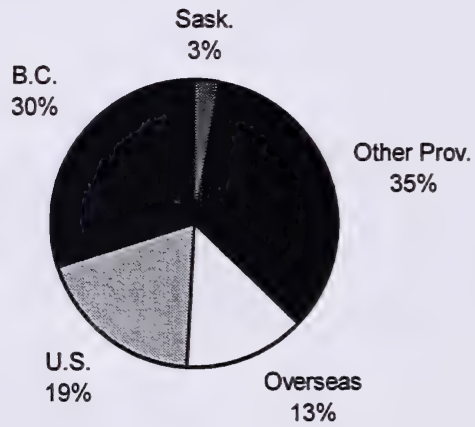

Note: Based upon 20 responses to Question 4.c out of 44 questionnaires received 


\section{Total Sales -- Alberta Head Office Suppliers}

Sales to industry sources outside of Alberta constitute a significant portion of both FISAA and non FISAA members, even after excluding those respondents with head offices located outside of Alberta (Figures 14 and 15)

Figure 14

\section{Gross Revenue of Companies With Head Offices in Alberta FISAA Members}

Total Gross Revenue $=\$ 800$ million (excluding power companies)

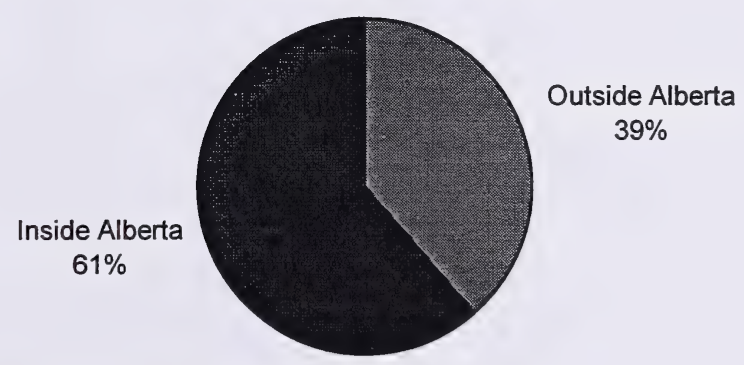

Note: Based upon 56 responses to Question 4.a.i out of 69 elegible returns.

Figure 15

\section{Gross Revenue of Companies With Head Offices in Alberta Non FISAA Members}

Total Gross Revenue $=\$ 300$ million

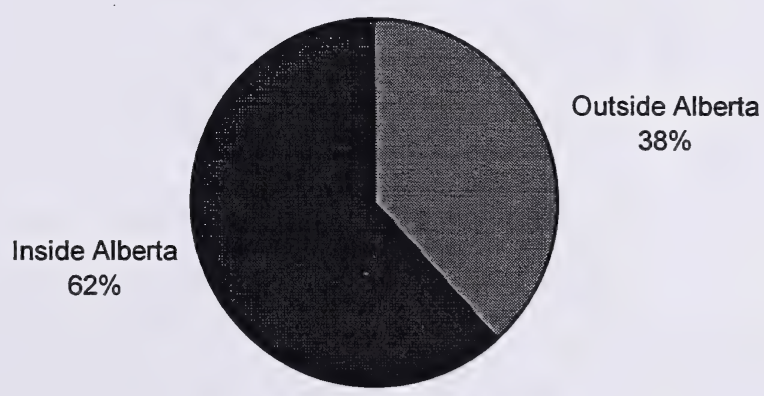

Note: Based upon 30 responses to Question 4.a.i out of 35 elegible returns. 
Forest Industry Sales Outside of Alberta (Alberta Head Office)

A review of forest industry revenue from outside of Alberta (again excluding companies with head offices located outside of Alberta) shows that Canadian markets, and British Columbia in particular, dominate (Figures 16 and 17).

Figure 16

\section{Revenue from Forest Industry Sources Outside of Alberta with Head Offices in Alberta - FISAA Members}

Total revenue $=\$ 112$ million

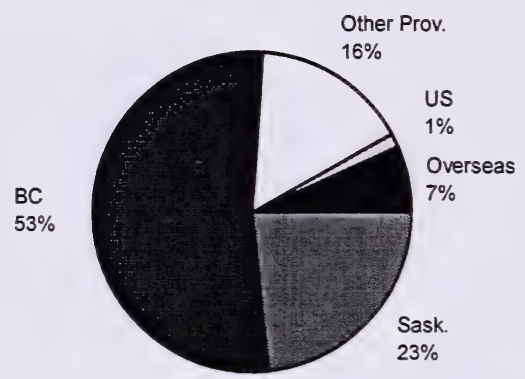

Note: Based upon 29 responses to questions 1.b and 4.a.ii out of 69 elegible returns.

Figure 17

\section{Revenue from Forest Industry Sources Outside of Alberta with Head Offices in Alberta - Non FISAA Members \\ Total revenue $=\$ 48$ million}

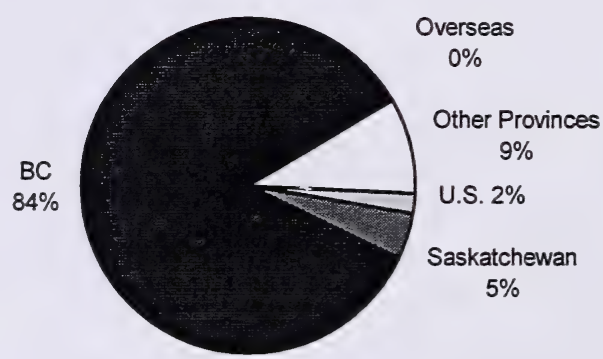

Note: Based upon 15 responses to questions 1.b and 4.a.ii out of 35 elegible questionnaires. 


\section{Alberta Work Force}

The range of work force size differs greatly among this industry sector. Some companies have less than five employees; others have more than 1000. For FISAA members, 21 to 50 employees was the leading category (Figure 18). Non FISAA members were generally smaller in size, from one to five and six to 10 employees (Figure 19).

\section{Figure 18}

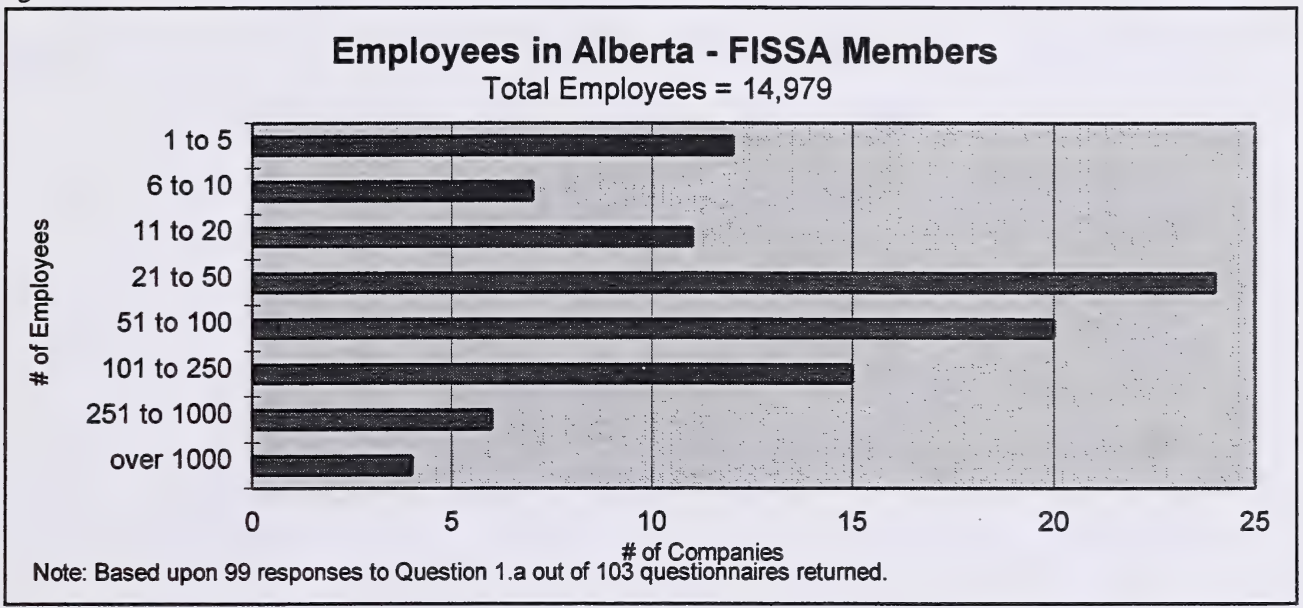

Figure 19

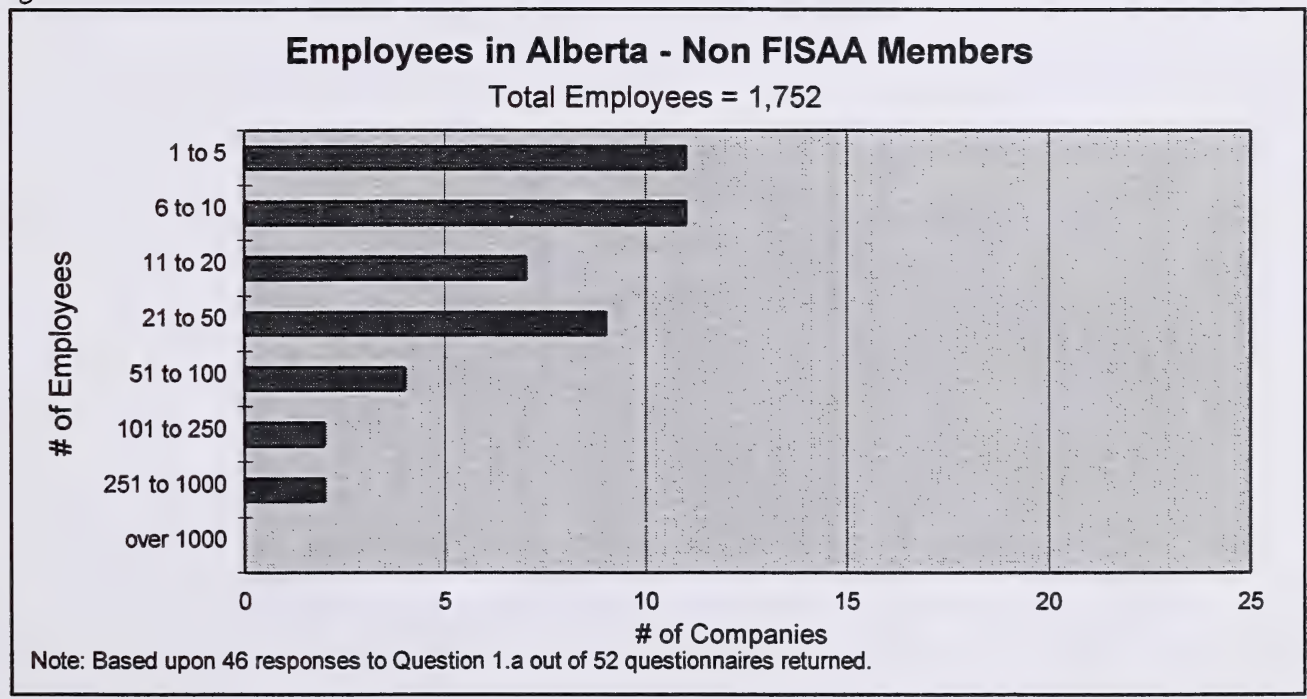




\section{Sector Related Employment}

Fourteen per cent of FISAA members' Alberta work force was supported directly by the forest industry (Figure 20). Among non FISAA members, the percentage of forest industrysupported employees were significantly greater, at 26 per cent (Figure 21).

Figure 20

\section{Total Alberta Employees FISAA Members}

Total Employees $=14,979$

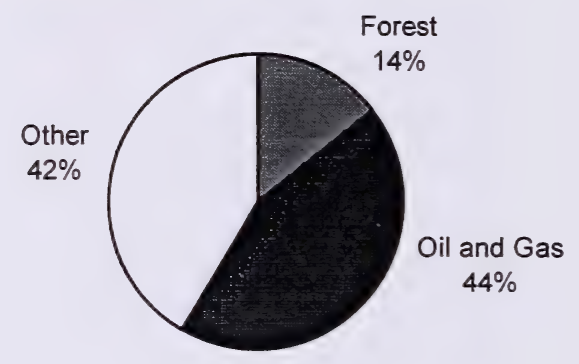

Note: Based upon 95 responses to Question 4.a.ii out of 103 questionnaires returned.

Figure 21

\section{Total Alberta Employees \\ Non FISAA Members}

Total Employees $=1,752$

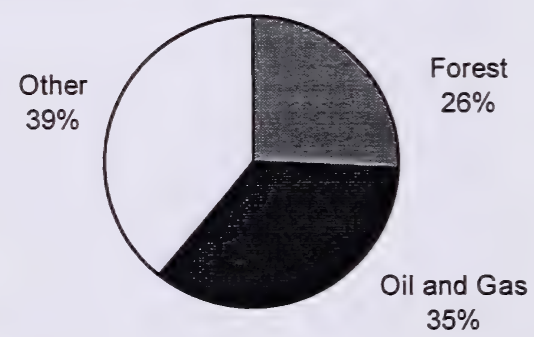

Note: Based upon 42 responses to Question 4.a.ii out of 52 questionnaires returned. 


\section{Head Office}

Of the respondents, the majority of FISAA members (50) listed Edmonton as their head office location (Figure 22). The second-most common location was Calgary (17), followed by Vancouver (13) and Toronto (10). For non FISAA members (Figure 23), the leading head office locations were Edmonton (18) and Calgary (7).

\section{Figure 22}

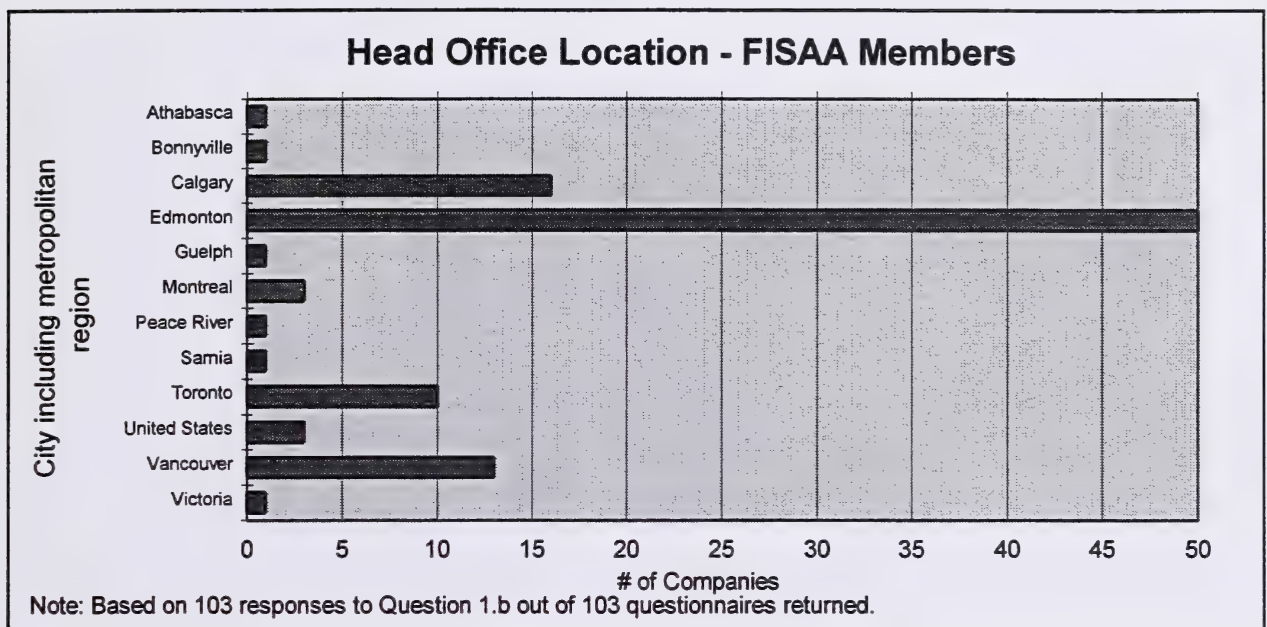

Figure 23

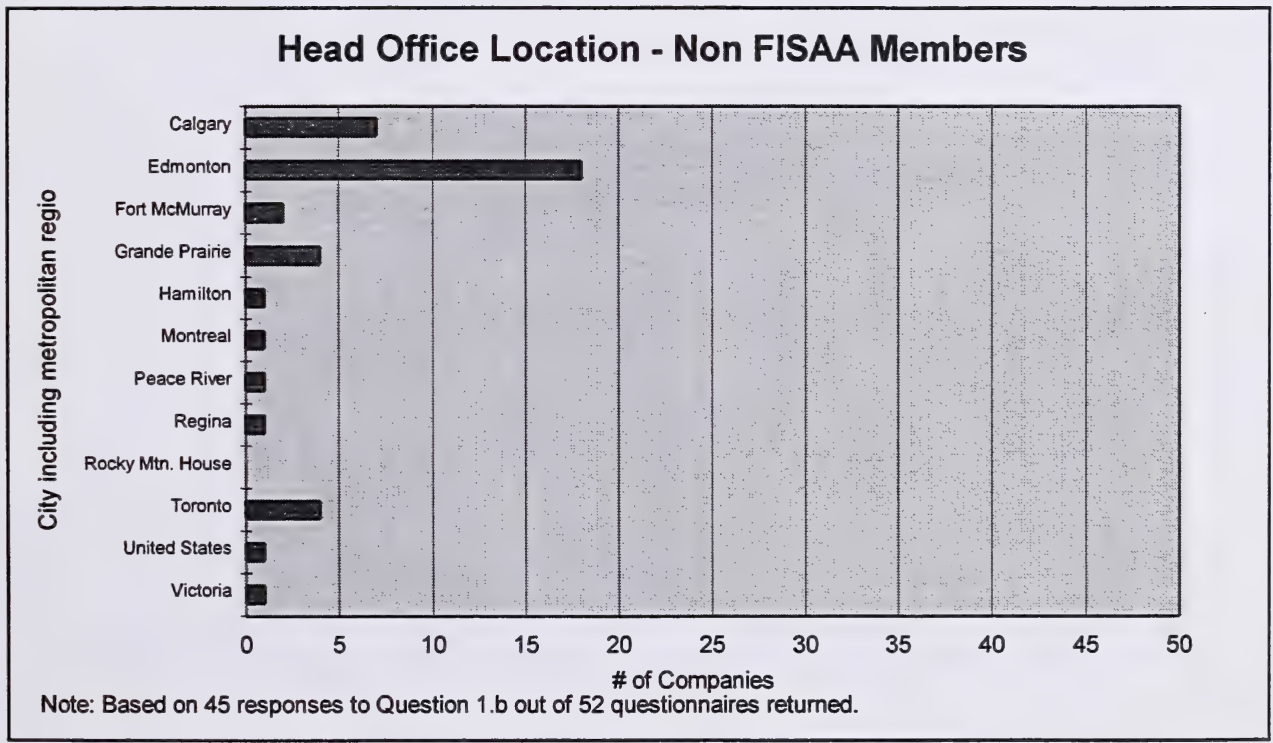




\section{Regional Offices (Alberta)}

Figures 24 and 25 show that FISAA members selected Edmonton and Calgary as leading regional office sites (49 and 43), as did non FISAA members (15 and 14). Other major selections were Grande Prairie (16 FISAA, 7 non FISAA); Fort McMurray (15 FISAA, 3 non FISAA); and Red Deer (11 FISAA, 6 non FISAA).

Figure 24

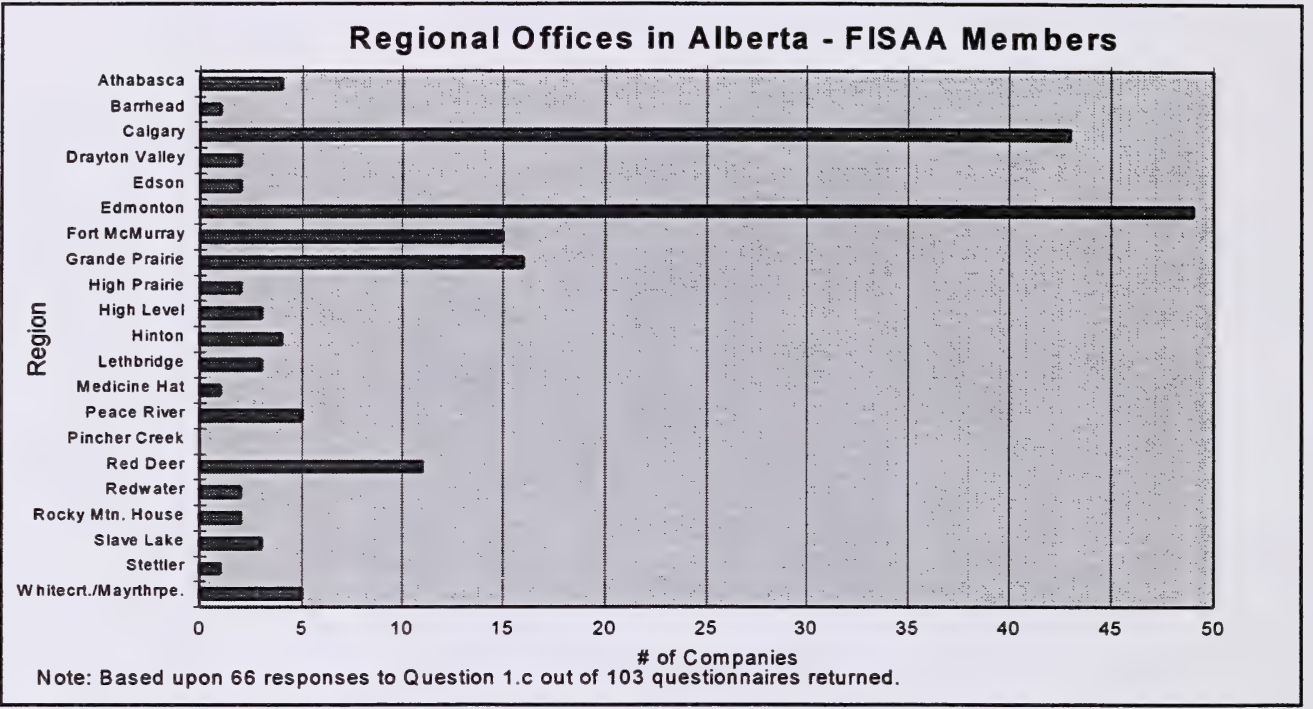

\section{Figure 25}

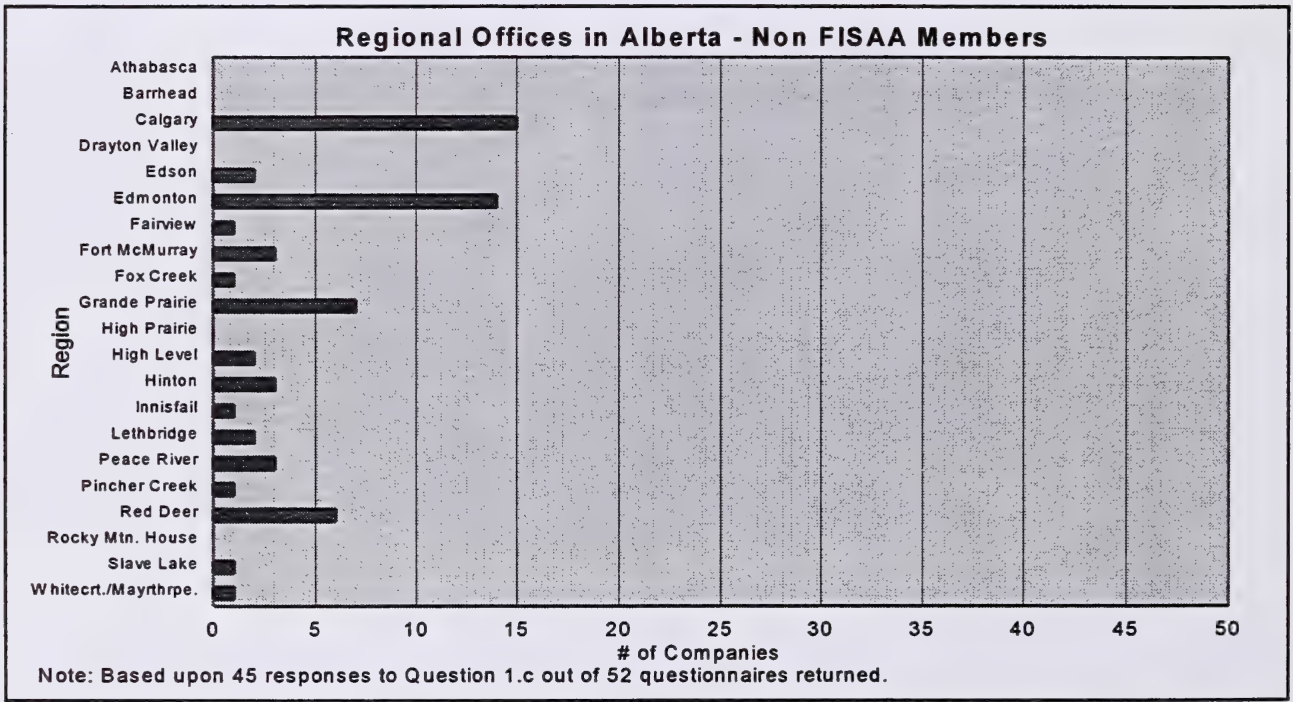




\section{Supply Industry Issues (Survey Results)}

\section{New Market Opportunities}

Question 3.b asked suppliers to name market areas they wished to enter in the next five years. As a response, FISAA members overwhelmingly mentioned three areas: panel board, pulp and paper and paper converter and packing. No category stood out among non FISAA members (Figures 26 and 27).

\section{Figure 26}

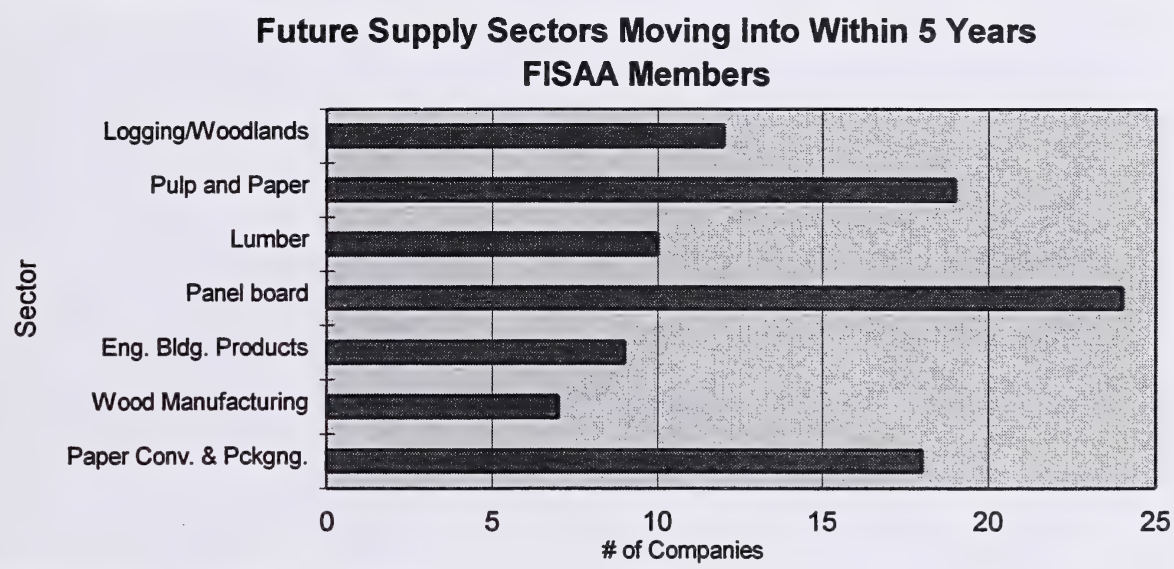

Note: Based upon 52 responses to Question 3.c out of 103 questionnaires returned.

\section{Figure 27}

\section{Future Supply Sectors Moving Into Within 5 Years Non FISAA Members}

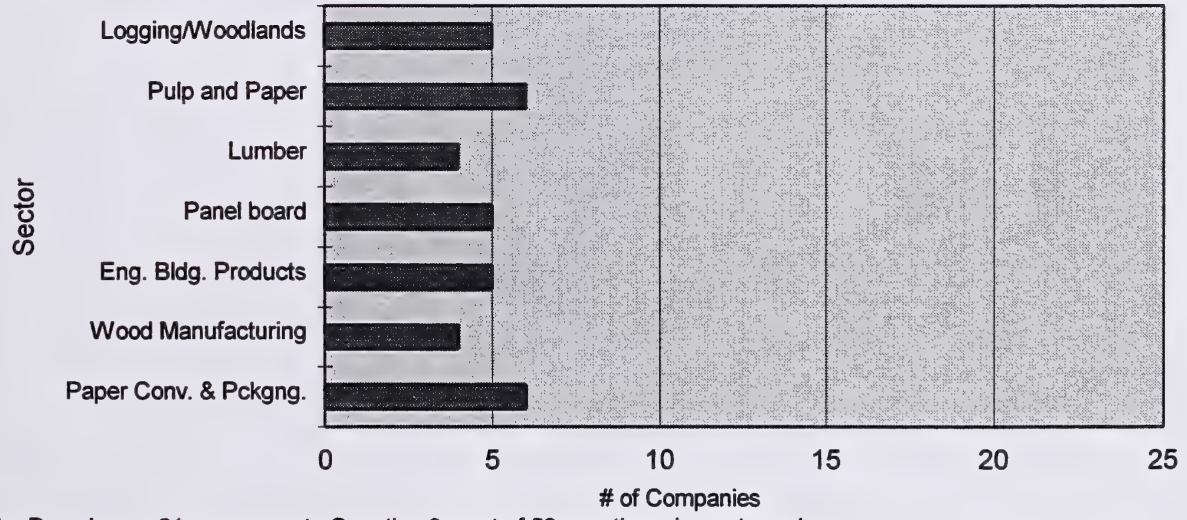

Note: Based upon 21 responses to Question 3.c out of 52 questionnaires returned. 


\section{Limiting Factors}

Supplier marketing--including a desire for improved knowledge of their client base, the development of contacts and networking opportunities--was the major factor that limits market growth among FISAA respondents. Other issues, including knowledge of client purchasing, were also important (Figure 28). Non FISAA members listed a range of issues as being nearly equal in importance (Figure 29).

Figure 28

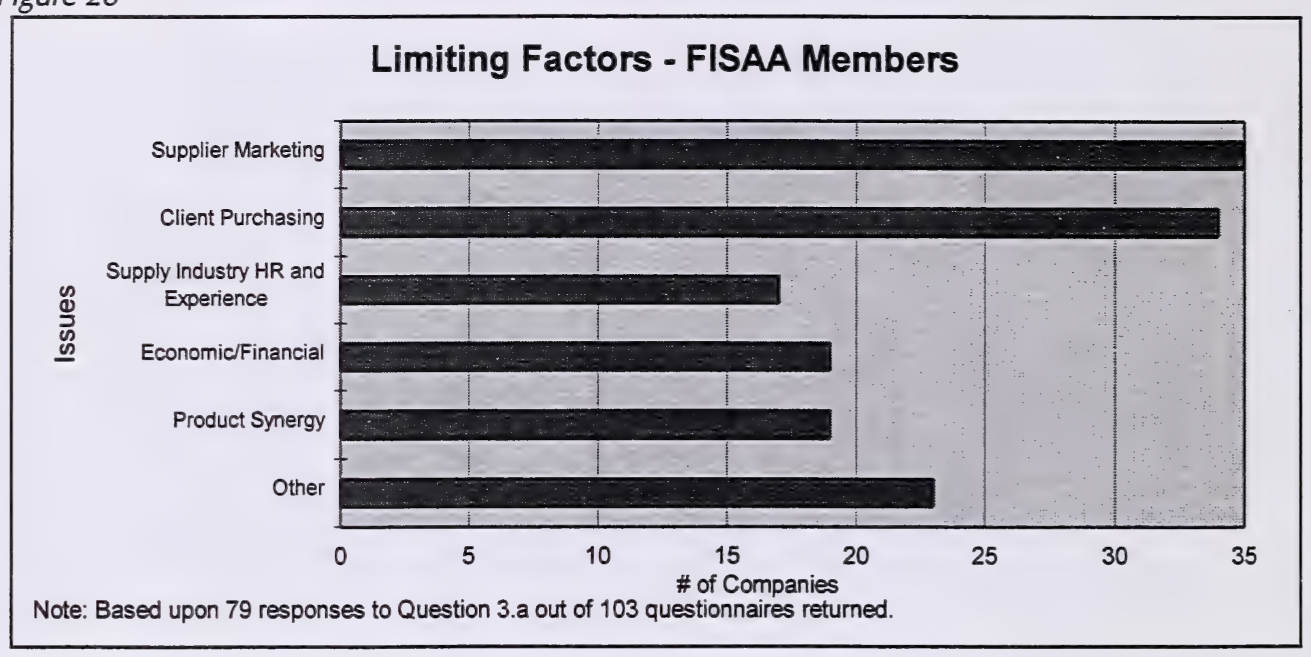

Figure 29

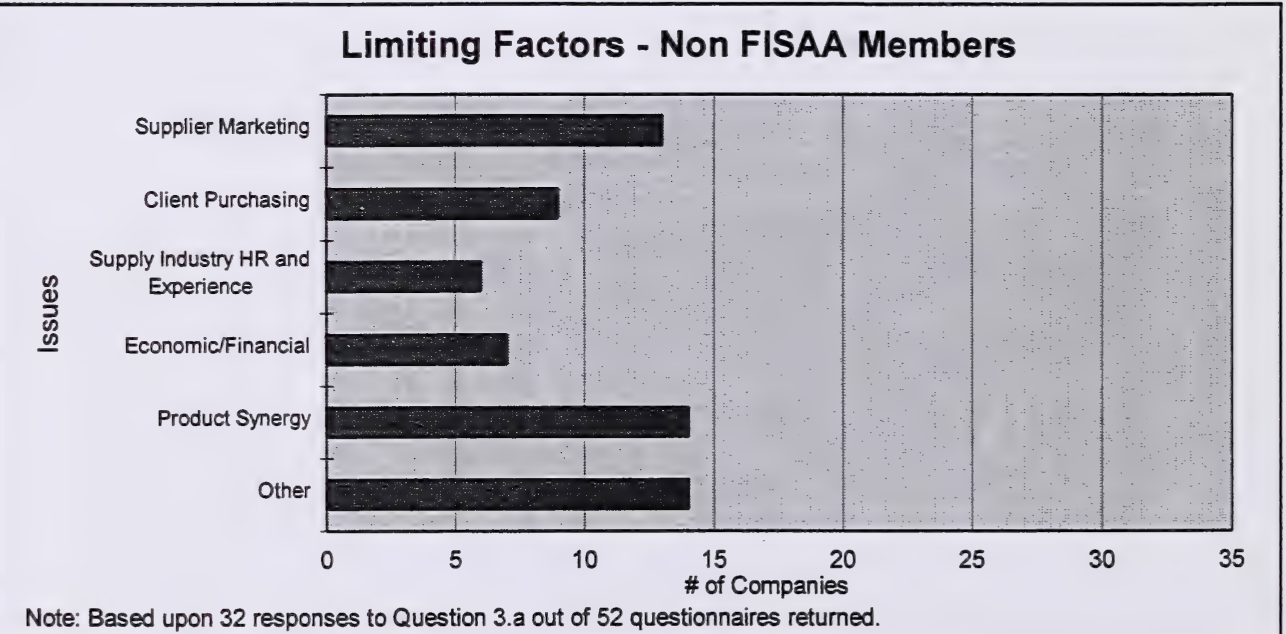




\section{Measures to Promote Growth}

Supplier marketing also ranks highly as a measure that would promote growth. Among FISAA members, 57 companies chose this category (Figure 30), while 16 non FISAA members identified marketing as the leading issue (Figure 31).

Figure 30

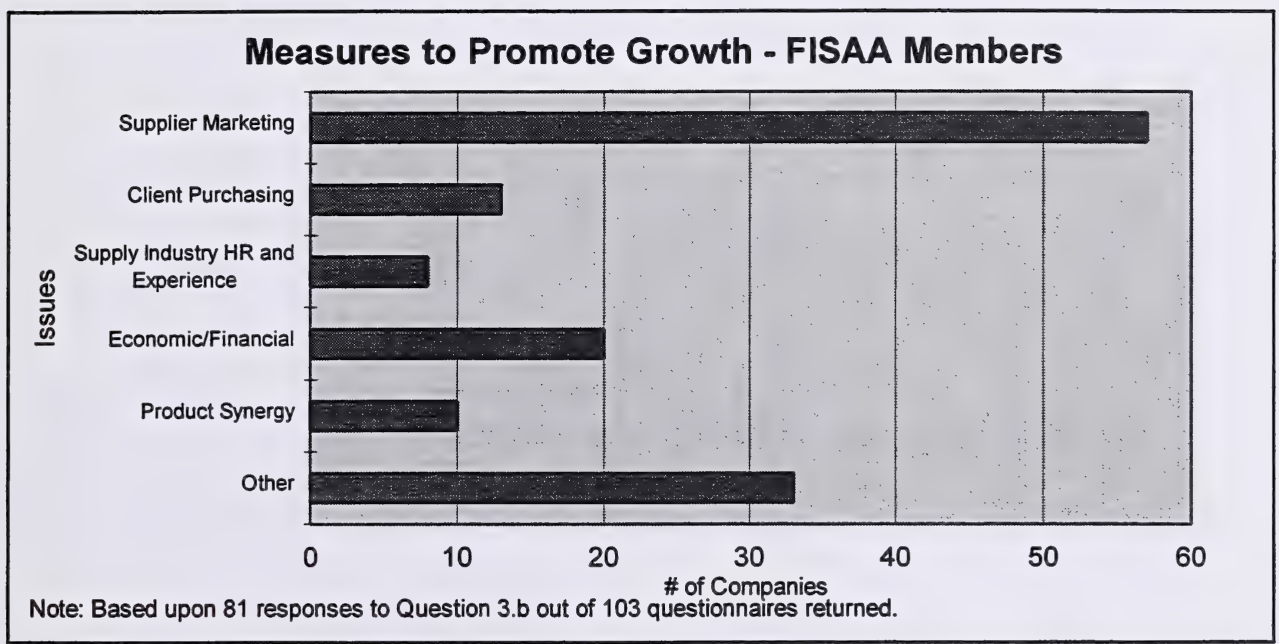

Figure 31

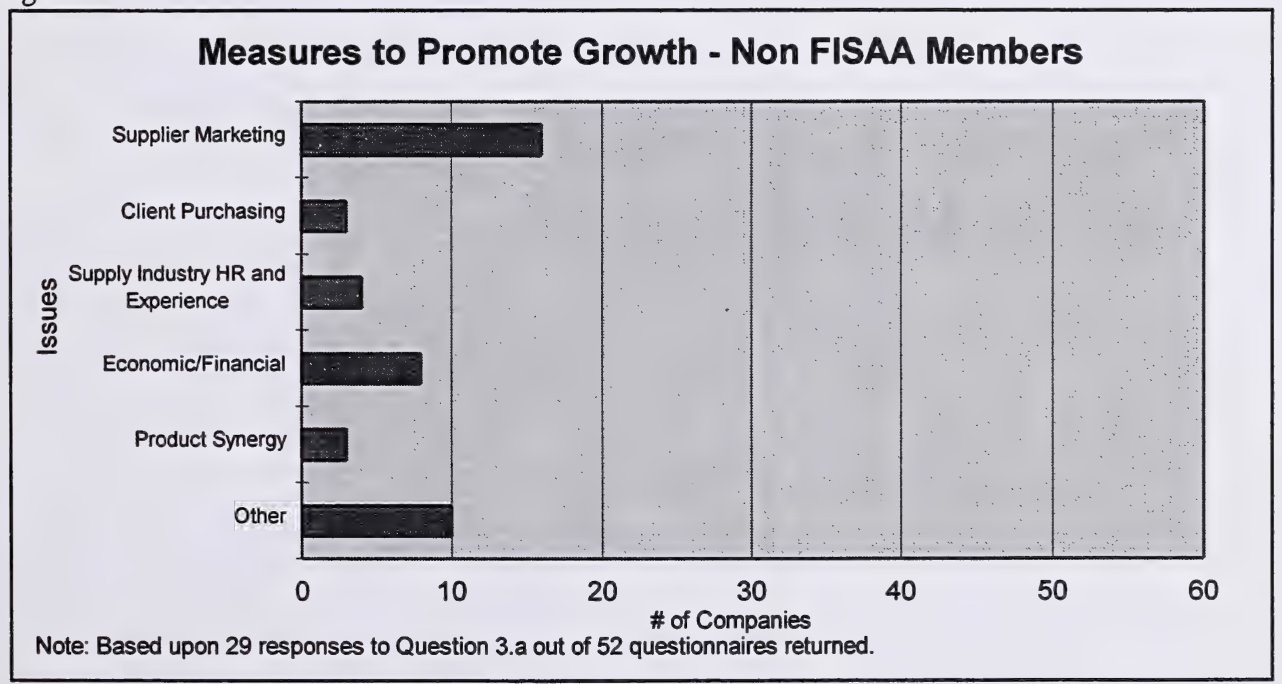




\section{Economic Improvement Opportunities}

Collectively, suppliers overwhelmingly selected the category "marketing" as an area that can be addressed by an industry association. In total, 66 FISAA members and 15 non FISAA members chose this category (Figures 32 and 33)

Figure 32

\section{Economic Improvement Opportunities FISAA Members}

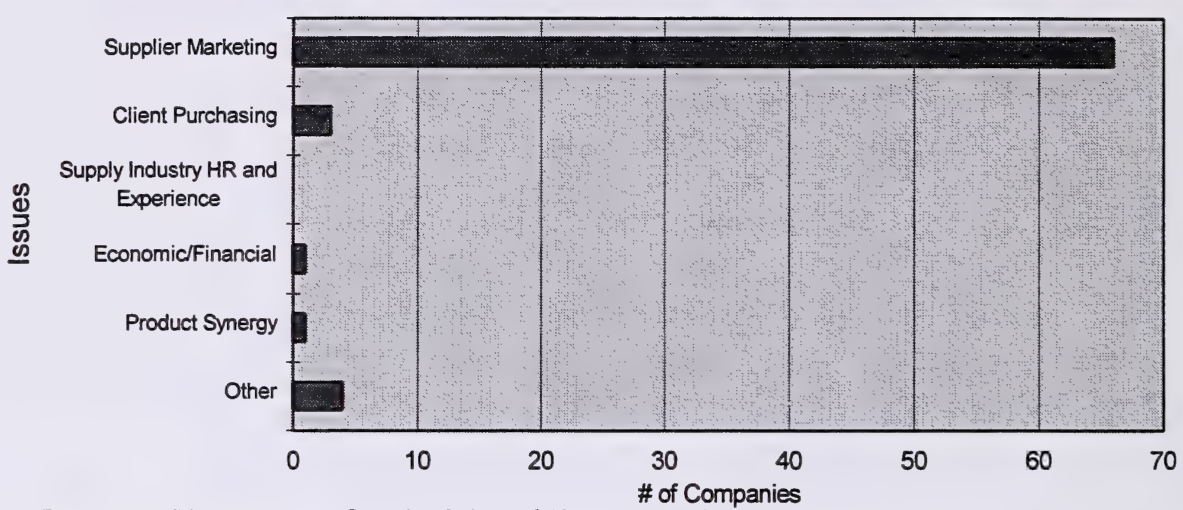

Note: Based upon 75 responses to Question 3.d out of 103 questionnaires returned.

Figure 33

\section{Economic Improvement Opportunities Non FISAA Members}

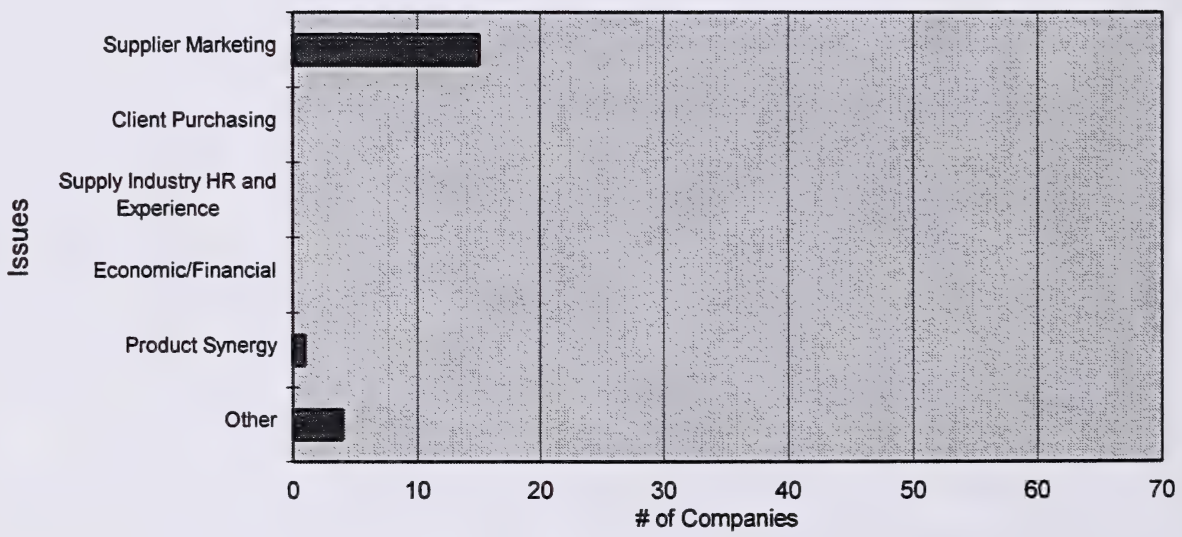

Note: Based upon 20 responses to Question $3 . d$ out of 52 questionnaires returned. 


\section{Supplier Marketing Issues}

Looking at the issue of marketing in greater detail, networking opportunities and knowledge of client base were the leading categories chosen by FISAA members as factors that would lead to market improvements (Figure 34). Knowledge of client base was the category most often selected by non FISAA members (Figure 35).

Figure 34

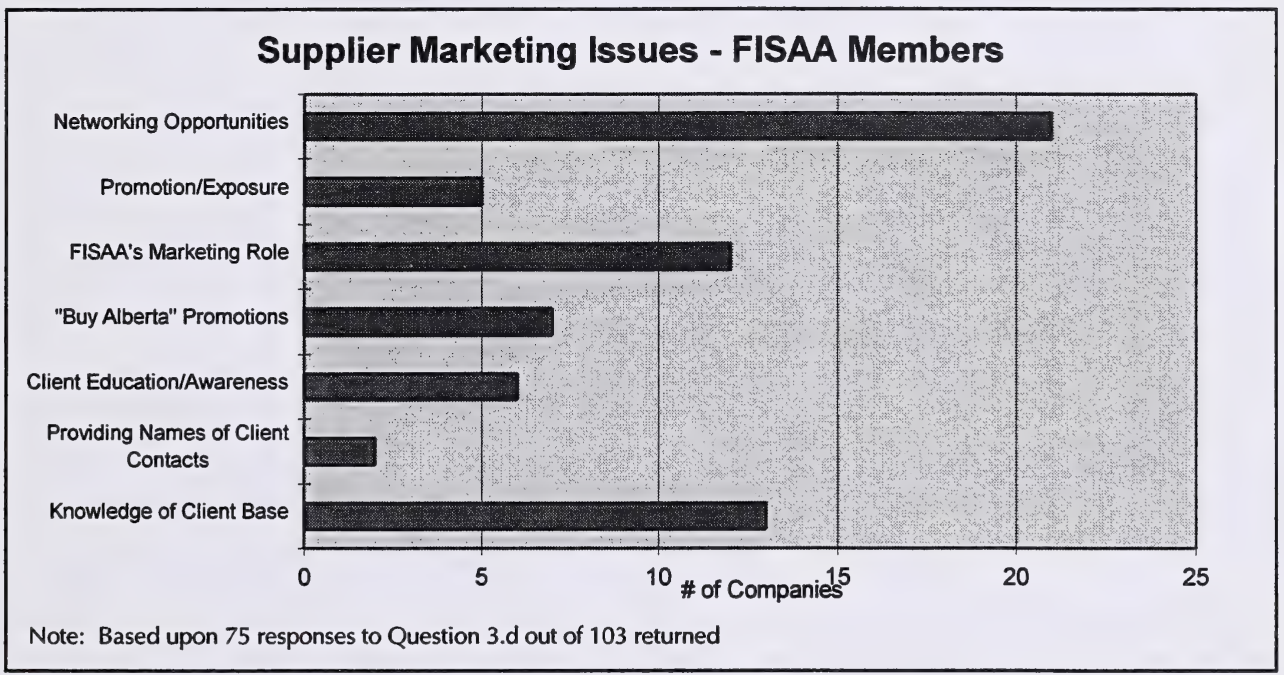

Figure 35

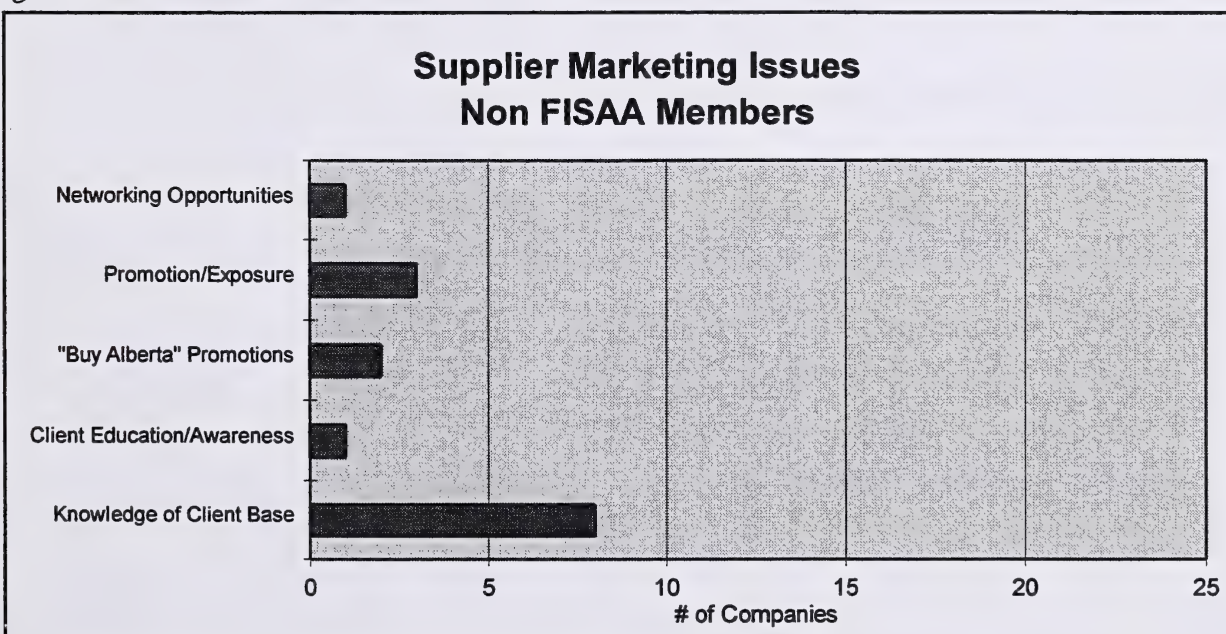

Note: Based on 20 responses to Question 3.d out of 52 returned 


\section{$\underline{\text { Summary }}$}

In terms of employment and revenue, the survey showed that the companies that responded to the survey are important contributors to Alberta's economy (Table 1).

\section{Table 1 Revenue and Employment in Alberta}

\begin{tabular}{|c|c|c|c|c|}
\hline & \multicolumn{2}{|c|}{ Alberta Sales Revenue } & \multicolumn{2}{|c|}{ Alberta Employees } \\
\hline & Total & Forest Industry* & Total & Forest Industry* \\
\hline FISAA Members & $\$ 2.86$ billion & $\$ 255$ million & 14,979 & 2,097 \\
\hline $\begin{array}{l}\text { FISAA Members excluding } \\
\text { Power Companies }\end{array}$ & $\$ 870$ million & $\$ 123$ million & 11,579 & 1,621 \\
\hline Non-FISAA Members & $\$ 232$ million & $\$ 67$ million & 1,752 & 456 \\
\hline
\end{tabular}

* Alberta forest industry revenue and employment levels are based on estimates by SENTAR Consultants Ltd. 


\subsection{WORKSHOP}

The study team used the survey results from the open-ended questions ( $3 . a, 3 . b$ and 3.d) as the basis for the workshop design. In the survey, most respondents identified marketing as the key to business growth. This category was further broken down into networking opportunities, knowledge of client base, the Alberta advantage, promotion/exposure and client/supplier education and awareness (Figures 34 and 35). Each of the five break-out groups was assigned a subject and asked to examine growth opportunities and factors that limit growth (morning session), as well as actions that may overcome the limiting factors (afternoon session). The results from the break-out group discussions are presented in the following section.

\subsubsection{Group A -- Networking Opportunities}

\section{Limiting Factors}

This group identified three areas where forest industry suppliers could do more to reach forest industry markets. These were:

- $\quad$ Access to proper contacts and the ability to meet with the decision-makers in the forest industry;

- The need for user/supplier forums; and

- The need for improved understanding of clients' technology/terminology. 


\section{Growth Opportunities}

As a response to these limiting factors, Group A outlined several steps that may lead to market growth:

- $\quad$ FISAA to organize selective networking opportunities (possibly with Alberta Forest Products Association);

- More trade shows in areas near mills;

- More organized tours and meetings with mills at mill-site; and

- Courses to help suppliers with forest industry terminology (to facilitate communication) -- Northern (NAIT) or Southern (SAIT) Alberta Institutes of Technology were suggested.

\section{Objectives and Actions}

This group identified actions that would enhance networking opportunities and improve the general understanding of the forest industry among suppliers.

\section{Organize Meetings between FISAA Members and Producers}

These meetings would increase the contact, and level of understanding between both the supplier and producer organizations (FISAA and AFPA) and between individual members of the two organizations. These could be accomplished through reverse trade shows held on an annual or semi-annual basis. Tours of mills could be arranged to coincide with meetings or trade shows.

\section{Education on Terminology}

In order to improve the understanding of the forest industry among suppliers, FISAA would arrange (in conjunction with the Province of Alberta) a form of education for suppliers. FISAA should set up a committee to deal with this issue, and meet with AFPA representatives to discuss what types of education would be valuable. Education could also take place through mill tours, trade shows and other options. 


\section{Education on Forest Industry Culture}

The group recognized that the forest industry has a very different corporate and functional culture than other industries they supply, including the oil and gas sector. Forest industry suppliers need to understand this culture, and can do so through the following steps:

- $\quad$ FISAA should review information on the British Columbia Institute of Technology $(\mathrm{BCIT})$ course on forest industry culture and the Environmental Services Association of Alberta (ESAA) course on training sales professionals;

- $\quad$ FISAA should assess options for implementing similar training programs;

- $\quad$ FISAA should undertake a feasibility study to assess the value of the program;

- $\quad$ FISAA should approach the government for assistance in developing criteria for such a program; and

- $\quad$ FISAA should establish a library of videos on mills.

\subsubsection{Group B -- Knowledge of Client Base}

\section{Limiting Factors}

Group B stated that most of the planning for new projects and expansions is kept confidential until the project is announced, and once the project is announced, many of the suppliers have already been identified. In other words, potential suppliers don't receive information about projects that they could participate in until after supplier decisions have already been made. In relation to this point, many suppliers do not know who makes the decisions, people working in mills may not have the time to teach forest industry suppliers and there is a general shortage of information on the forest industry.

\section{Growth Opportunities}

The limitations outlined above can be overcome by increasing suppliers' knowledge base and general level of education on the forest industry. 


\section{Objectives and Actions}

Group B outlined two strategies that may lead to growth in suppliers' access to the forest industry market.

Database on Western Canadian Forest Industry Companies and Consulting Engineers FISAA should collect and maintain a database of British Columbia, Alberta, Saskatchewan and Manitoba forest producers, and include the names of Western Canadian consulting engineering companies in the database.

\section{Workshop on Procurement Practices}

FISAA should deliver a one- or two-day workshop on forest industry procurement practices. FISAA and the government of Alberta would develop terms of reference, and an educator would also be on the team. Interested professionals from throughout the western provinces would be invited to attend. This seminar would be a money-making venture for FISAA.

\subsubsection{Group C -- The Alberta Advantage}

\section{Limiting Factors}

Group $C$ examined the issue of enhancing the reputation of Alberta suppliers within the forest industry in Alberta. The group identified four points that may limit the market growth for suppliers in Alberta. The first three points relate the perceptions of the forest industry; the final point relates to forest industry suppliers:

- $\quad$ The perceived lack of benefits from Alberta suppliers;

- The perceived benefits from external suppliers;

- The perceived lack of local products/services; and

- A lack of marketing awareness. 


\section{Growth Opportunities}

Measures that would help overcome the limitations and lead to market growth include the promotion of Alberta's forest supply industry by FISAA and its members and an enhanced market awareness among forest industry suppliers.

\section{Objectives and Actions}

Group C described a series of steps that would lead to the promotion of Alberta suppliers and an enhanced market awareness among these suppliers.

\section{Communicate the Strength of Alberta's Forest Supply Industry to its Customers}

This can be accomplished by:

- Independent companies continuing face-to-face marketing with the forest industry;

- $\quad$ FISAA providing company profiles and resource information to forest producers;

- The government promoting "Buy Alberta" or "if you're looking, look locally first..." campaigns;

- $\quad$ FISAA arranging more reverse trade shows;

- Heightening FISAA members' familiarity with the products and services offered by fellow members;

- $\quad$ Establishing a library of videos on mills;

- $\quad$ Establishing an information system on its members (by FISAA); and

- $\quad$ FISAA, together with the Province of Alberta, developing a glossary of forest industry terminology.

\subsubsection{Group D -- Promotion/Exposure}

\section{Limiting Factors}

Three issues were seen as factors which limit market growth of Alberta's forest industry suppliers: (1) Suppliers themselves do not always recognize the opportunities that are 
available to the them for market growth, (2) the forest industry is not fully aware of the abilities of Alberta's suppliers and (3) marketing to the forest industry is not as effective as it could be due to a lack of knowledge of the forest industry and the high cost of marketing.

\section{Growth Opportunities}

In order to overcome these limitations, Group D suggested two opportunities:

- $\quad$ Expose the supply industry to the opportunities available in the forest industry sectors. This could be accomplished through local buying, trade missions and infrastructure development; and

- $\quad$ FISAA could play a role in promotion/exposure.

\section{Objectives and Actions}

The overall objective of improving the promotion of the supply industry is to encourage forest producers to recognize purchasing opportunities in Alberta. This could be accomplished by enhancing producers' access to information on Alberta suppliers.

\section{Database Containing Information on Suppliers and Producers}

Forest producers should have convenient access to information on forest industry suppliers. This could be achieved by developing an electronic database of supply companies. This database, which would be coordinated by FISAA, would also include names of forest producers and design engineers. FISAA should contact the AFPA and Alberta Economic Development and Tourism to determine whether a database would be used by forest producers. 


\subsubsection{Group E -- Client/Supplier Education and Awareness}

\section{Limiting Factors}

From the discussion, Group E members agreed that lack of education both of the suppliers and the client was a major limitation. The client needs to know what is available in Alberta, and the supplier needs to know what the client wants.

\section{Growth Opportunities}

Several points were identified as factors that would lead to market growth:

- The timing of information on forest industries should coincide with decisions on mill purchases (maintenance/operations/expansions/construction);

- $\quad$ Suppliers can do more to make their services known to clients and potential clients; and

- $\quad$ Suppliers and producers can exchange information through controlled environments (e.g., a workshop).

\section{Objectives and Actions}

Forest industry suppliers should consider two general programs that would enhance their market access:

- The compilation of information on forest producers and forest industry suppliers; and

- Development of a system of notifying suppliers about upcoming projects.

\subsubsection{General Workshop Comments}

Following the second set of presentations, workshop participants had a series of additional comments on several workshop discussion areas. 


\section{Database/Intelligence}

- Must be user-friendly;

- Some caution is needed so that producers are not inundated with information from suppliers;

- A database cannot replace the "legwork" that is required to ferret out useful information;

- Information should be provided in a form that can be shared by members;

- Companies listed on the database must be credible;

- The liabilities involved with owning and operating a database must be clearly understood and accepted; and

- Instead of database being a list of everything we know about producers, create a database that provides everything that producers want to know about supplier products and services.

\section{Marketing}

- $\quad$ Effective marketing still comes down to "people on people".

\section{Supplier Contracts}

- Many producers are moving toward long-term supplier contracts in the form of partnerships, which include codes of practice for the suppliers; and

- Consider developing a rating system for companies--bid lists are becoming passé 


\subsection{LIMITATIONS AND GROWTH OPPORTUNITIES}

Based upon the supplier survey, workshop results, and forest producer interviews, the limiting factors preventing growth in the forest supplier sector in Alberta relate to supplier marketing, client purchasing, and supplier qualifications and experience.

\subsection{SUPPLIER MARKETING}

\section{Limitations}

Supplier marketing was the most frequently mentioned obstacle to growth within the Alberta forest supply sector. Many of the suppliers appear to be reluctant to invest marketing time and expenses into the forest industry producers sector on any consistent basis. This fact is revealed in comments such as "knowing the right people to talk to at each company", "unaware of opportunities", "contacting correct decision maker at the appropriate time", "difficult to access project information and people", "distance -- do not have branch offices close", "lack of sales force to cover industry", "my time", "time, resource and manpower required to visit all mills", "knowledgeable sales/marketing force".

\section{Growth Opportunities}

Individually, corporations saw the need to provide more marketing man hours to the forest industry sector as the principle way to promote growth in the forest industry supply sector. Also, there appears to be a preoccupation with the construction phase of forestry activities within the inner workings of FISAA. Although this remains as a very important sector, it typically cycles every seven years or so and promotes a similar marketing/sales relationship with the forest industry producer. On the other hand, a supplier who provides products and services to the operating side of the business has a better chance of establishing longer term relationships with the producer and is already there when the next construction phase presents itself. It is noteworthy that only 22 per cent of FISAA members and 10 per cent of non FISAA members surveyed indicated that they were supplying the construction sector of the forest industry. 
Other initiatives involved learning more about the industry technology and needs, possibly through an overview course given through an educational institution.

\subsection{CLIENT PURCHASING}

\section{Limitations}

Another limitation to growth noted was client purchasing habits; suppliers perceived that some forest industry producers prefer out-of-province suppliers to those in Alberta. This was based in part upon such factors as buying spare parts from the original manufacturer of equipment, a reliance on B.C. specifications and suppliers, preference for European suppliers, out of province engineering/contractors bringing in their favorite non-Alberta suppliers on capital projects, and the lack of education of company personnel regarding client needs and manufacturing processes.

\section{Opportunities}

Increased use of reverse trade shows, mill tours and a supplier on-line database were identified as opportunities for increasing client and engineering consultants' knowledge on the capabilities of Alberta suppliers.

The government and individual companies could also continue to maintain an Alberta industrial benefits strategy as general marketing program rather than a regulatory requirement. Such a program currently exists within Alberta, and is designed to ensure Alberta suppliers receive a full and fair opportunity to compete.

\subsection{SUPPLIER QUALIFICATION AND EXPERIENCE}

\section{Limitations}

This limiting factor was identified during interviews with the Forest Industry manufacturers and was not specifically identified at the workshop -- other than to offer industry overview courses to supplier marketing representatives. Many of the companies interviewed supply other sectors of the economy besides forestry. Alberta forest producers need reassurance 
that Alberta suppliers have the necessary qualifications and experience to deliver quality products and services in a timely and competitive fashion. This is particularly critical during the construction phase and during operations on major pieces of equipment.

Since most of the major equipment is purchased outside of Canada, there is a natural tendency on the part of forest producers to look to the original manufacturer for "after sales service" in the supplying of spare parts and equipment upgrades.

\section{Opportunities}

Although not identified in the workshop on the supplier survey, specific forest industry supplier knowledge and experience could be obtained through the hiring of people already in the forest supplier business in other provinces and the United States

With respect to machinery and equipment sales and manufacturing, Alberta companies would enhance their market position by developing more joint venture relationships with out-of-province and off-shore suppliers and manufacturers. Although some of these alliances have already taken place, more could be done in this area, particularly if the "Alberta Advantage" is marketed as the place to do business in western North America.

By linking with an Alberta partner, major equipment manufacturers and suppliers could serve forest producers in British Columbia, Saskatchewan, Manitoba/NW Ontario and possibly the northwest United States.

Joint-venture partnerships should be encouraged through a number of initiatives of the Forest Industry Suppliers Association of Alberta.

- Alberta Economic Development and Tourism can assist FISAA by organizing technical missions to forest industry equipment and machinery trade fairs, such as the Annual International Panel and Engineered Wood Technological Expo in Atlanta. 
- $\quad$ Seminars could be arranged to introduce suppliers with key forest industry equipment and machinery suppliers from countries such as Germany, Sweden, Finland and the United States. These seminars may be facilitated by a forest industry expert.

Where appropriate, individual forest industry equipment manufacturers would visit Alberta to discuss the development of joint-venture relationships with Alberta suppliers.

The provincial government can play a significant role in developing an equipment and machinery design and manufacturing capability among Alberta suppliers. This process should encourage forms of subcontracting that makes economic sense to Alberta firms.

The province can enhance suppliers' capability by arranging direct and indirect discussions with equipment and machinery suppliers and manufacturers outside of Alberta. In this area, the Alberta Government can:

- Facilitate technical visits by Alberta suppliers to relevant trade shows;

- Facilitate joint-venture discussions between Alberta suppliers and suppliers/manufacturers from outside of Canada; and

- $\quad$ Support familiarization tours by Alberta suppliers to suppliers/manufacturers in countries such as Sweden, Finland, Germany and the United States. 


\subsection{CONCLUSIONS AND RECOMMENDATIONS}

\subsection{INDIVIDUAL COMPANIES}

Individual companies need to specifically earmark marketing (time and expenses) dollars to the forest producers if they wish to grow in the forest supply sector. In the final analysis, individual companies need to put forward the marketing effort and not rely exclusively upon an industry association such as FISAA or the provincial government to do their marketing for them.

Having stated this, however, there are areas where FISAA and the provincial government can help to create a better business environment and these initiatives are discussed later in this section of the report.

Marketing initiatives include regular calls and personal visits to the forest producers so that suppliers know who the people are and how decisions are made. New products and services need to be communicated to project managers, operators and central purchasing staff by knowledgeable marketing/sales staff who are familiar with industry processes and needs. Attendance at reverse trade shows and associated mill tours would be mandatory.

Marketing personnel can be developed internally or acquired from outside the company. It is probably better to educate and train marketing personnel in the technical aspects of the forest industry rather than vice-versa.

As mentioned previously, individual companies should consider joint ventures with outside suppliers of major equipment to offer a local market presence for "after sales service" and the supply of spare parts. The provincial government and the forest producers can assist in identifying gaps in the Alberta forest supply industry where joint venture opportunities may lie. These joint venture opportunities should be focused upon a market supply area larger than just Alberta, and include British Columbia and Saskatchewan as a minimum, and possibly Manitoba/northwestern Ontario and the northwestern United States. 


\subsection{FISAA}

A number of initiatives were suggested throughout the course of this study where FISAA may be able to assist in providing a growth environment for its members and the industry in general.

\subsubsection{Reverse Trade Shows/Mill Plant Tours}

The concept of reverse trade shows was considered by most to be a very positive method to link customers and suppliers. However, based upon the membership survey, alternative locations to Whitecourt should be considered for future trade shows. Other centres that FISAA should consider include Grande Prairie, Athabasca/Slave Lake and Red Deer.

Mill and plant tours in the local area should be included as part of the reverse trade show program. A FISAA committee should work through the Alberta Forest Products Association (AFPA) and individual area forest producers to organize and host reverse trade shows.

\subsubsection{Forest Industry Education}

FISAA could sponsor a one- or two-day forest industry overview course for owners, managers and marketing specialists. Preliminary inquiries made to several post-secondary institutions (e.g., British Columbia Institute of Technology, Northern Alberta Institute of Technology, University of Alberta, Athabasca University, etc.) identified the University of Alberta - Faculty of Extension as being interested in holding such a course. The Faculty presently offers a two-day course on forestry that focuses on trees, silviculture, harvesting and natural processes. The approximate cost to mount such a course could range from $\$ 2,500$ to $\$ 3,000$ for 30 students if the course was sponsored by FISAA. FISAA may wish to poll its members for interest, willingness to pay, etc., and if there is sufficient interest, contact the $U$ of $A$ - Faculty of Extension to work out the details. 


\subsubsection{Resource Library}

FISAA may consider compiling a resource library of material that could be made available to members. Included in the library could be industry videos, corporate brochures, environmental impact assessments, and so on. Prior to establishing such a service, demand should be found to be sufficient to justify the cost. One way to measure demand would be through the annual membership survey, by asking whether or not members would pay for the service on a cost-recovery basis.

\subsubsection{Supplier On-line Database}

Preliminary indication from the forest industry producers was that if such a system existed they would probably use it. However, some of the larger producers have their own computer supplier database. It is recommended that a feasibility study be completed on this database should there be sufficient interest expressed by the membership to take the next step. Such a feasibility study should address issues of content, accessibility, confidentiality and cost/benefit.

\subsubsection{Revise Annual FISAA Membership Survey}

This annual survey should be revised to include a poll surrounding recommendations made during the course of this study. Also, every member needs to answer the following question: "How many people does your organization employ in Alberta (based on fulltime equivalent positions)?"

When the collective Alberta employment is known, then the 40 per cent of FISAA survey results obtained in this study can be aggregated upwards to 100 per cent with a degree of confidence in order to present an accurate profile of the entire FISAA membership.

\subsubsection{Forest Industry Profile -- Western Canada}

FISAA may wish to develop, with the provincial government, a complete and accurate database listing all Alberta, British Columbia, Saskatchewan and Manitoba forest industry producers. This list would include locations, products, production type, key mill 
operating personnel and head office. This database should also be extended to include a list of consulting engineering companies (wherever based) which service the industry in the western provinces. This database should be updated annually using FISAA newsletter mail-outs.

\subsection{PROVINCE OF ALBERTA}

\subsubsection{Export Strategy}

According to the membership survey, more than $\$ 100$ million of forest supply business was attributed to activity outside of Alberta by forest industry suppliers with head offices in Alberta (Figure 16). More than three-quarters of these "exported" services were destined for British Columbia and Saskatchewan (53 and 23 per cent respectively). Other provinces accounted for 16 per cent; while the "overseas" category represented seven per cent. The United States only accounted for one per cent.

When assessing the source of revenue for all FISAA and non FISAA members (Figures 12 and 13), 19 per cent of their gross revenues from the forest industry outside of Alberta were attributed to the United States. This might suggest that the province should continue to look into developing a strategy to market Alberta's forest industry suppliers into the northwest United States.

\subsubsection{Economic Forecasts}

One recommendation from the workshop was the provision of regular financial updates and forecasts on the forest industry to FISAA members. The suggestion was that some financial information could be obtained from the AFPA or Canadian Pulp and Paper Association (CPPA).

In fact, such information may be difficult to obtain from the AFPA and CPPA, particularly forecasts of commodity prices. These analyses are carried out by individual companies and are proprietary to those companies. Any financial reviews that exist are usually in a general form that update the status of the industry, rather than providing forecasts. 
Nevertheless, forest industry suppliers could obtain financial information from other sources, such as independent consultants or analysts or from Alberta Economic Development and Tourism. The forecasts could be updated annually or biannually.

\subsubsection{Alberta Engineering Content}

Consulting engineering firms play an important role in any forest industry project. They not only design the facilities, but can also be directly involved in the procurement of goods and services or provide recommendations to the project proponents on which goods, services or suppliers to source and/or use.

Many of the Alberta forest industry suppliers saw a direct link between out-of-province consulting engineering and out-of-province equipment suppliers being deployed on Alberta forest industry projects.

Although some progress has been made recently to increase the Alberta engineering content, most forest industry projects are engineered by out-of-province consulting firms. In most cases, out-of-province consulting engineering firms do not know or are not familiar with the supply capabilities in Alberta, or they carry out their procurement function outside the province. This makes it difficult for Alberta suppliers to access supply opportunities.

The Alberta government can do more to encourage forest industry developers to use Alberta-based consulting engineering expertise (e.g., de-bundling of the engineering tender to match capabilities in Alberta). Where little or no engineering capability exists, the government can encourage (with the support of the developer) forest consulting engineering firms elsewhere to form joint ventures with Alberta-based engineers or establish a presence in Alberta. By so doing, accessibility to Alberta suppliers will likely be increased during construction phases of forest industry projects. 


\subsection{IMPLEMENTATION}

The implementation chart that follows is prepared to summarize the consultant's recommendations and to identify responsibilities, time frames and priorities.

It will be important to distribute the results of the study as widely as possible to prompt further discussion amongst and between the suppliers and producers. This can be achieved by having the study sponsors make a presentation of the findings to both the FISAA and AFPA Boards of Directors and senior staff. Also, the 500 copies of the study should be distributed to both FISAA and AFPA members, plus the non-FISAA survey participants.

Other important initiatives to be undertaken include devising an export strategy for Alberta-based suppliers for the northwestern United States, provision of a forest industry overview course, profiling FISAA's membership, undertaking more reverse trade shows in new locations, annual economic forecasts and increasing Alberta engineering content in forest industry projects.

However, the most important initiative to increase the business of the Alberta forest industry supplier sector must come from the individual businesses themselves. As acknowledged by the suppliers themselves in the survey, the greatest limitation and opportunity to stimulate growth is in the area of marketing. A challenge should go out to FISAA members to concentrate and focus upon this important aspect of their business, starting in 1995. 
Table 2 Implementation Steps

\begin{tabular}{|c|c|c|c|c|}
\hline \multicolumn{2}{|c|}{ Initiative } & \multirow{2}{*}{$\frac{\text { Responsibility }}{\text { Individual Companies }}$} & \multirow{2}{*}{$\frac{\text { Timing }}{\text { On-going }}$} & \multirow{2}{*}{$\frac{\text { Priority }}{1}$} \\
\hline A. 1 & $\begin{array}{l}\text { Forest Industry Supplier } \\
\text { Marketing }\end{array}$ & & & \\
\hline A. 2 & Knowledgeable Marketing Staff & Individual Companies & On-going & 1 \\
\hline A. 3 & Joint-Ventures & Individual Companies & On-going & 2 \\
\hline B.1 & $\begin{array}{l}\text { Reverse Trade Shows/Mill Plant } \\
\text { Tours }\end{array}$ & $\begin{array}{c}\text { FISAA and AFPA Host Next Trade } \\
\text { Show in: Grande Prairie } \\
\text { Red Deer }\end{array}$ & $\begin{array}{l}1995 / 96 \\
1996 / 97 \\
\end{array}$ & $\begin{array}{l}1 \\
1\end{array}$ \\
\hline B.2 & Forest Industry Overview Course & FISAA/U of A Faculty of Extension & January 1996 & 1 \\
\hline B.3 & $\begin{array}{l}\text { Revise Annual FISAA } \\
\text { Membership Survey }\end{array}$ & FISAA & Fall 1995 & 1 \\
\hline B.4 & $\begin{array}{l}\text { Supplier On-Line Database } \\
\text { Feasibility Study }\end{array}$ & FISAA/Province of Alberta & $1995 / 96$ & 3 \\
\hline B.5 & Resource Library Feasibility & FISAA & Fall 1995 & 3 \\
\hline B.6 & $\begin{array}{l}\text { Forest Industry Profile -- Western } \\
\text { Canada }\end{array}$ & FISAA & Fall 1995 & 2 \\
\hline B.7 & $\begin{array}{l}\text { Consultant to Present Findings to } \\
\text { FISAA/AFPA }\end{array}$ & Consultant/FISAA/AFPA & September 1996 & 1 \\
\hline B. 8 & Distribute Copies of this Study & $\begin{array}{l}\text { FISAA/AFPA/Province of } \\
\text { Alberta/non FISAA respondents }\end{array}$ & Fall 1995 & 1 \\
\hline B.9 & Profile FISAA Membership & FISAA/Consultant & $\begin{array}{l}\text { Following Next } \\
\text { Membership } \\
\text { Survey }\end{array}$ & 1 \\
\hline C.1 & Export Strategy -- U.S. Focus & Province of Alberta/FISAA & Yearly, On-going & 1 \\
\hline C. 2 & $\begin{array}{l}\text { Economic Forecasts/Distribution } \\
\text { to Suppliers }\end{array}$ & Province of Alberta/FISAA & Yearly/On-going & 1 \\
\hline C. 3 & $\begin{array}{l}\text { Alberta Engineering Content -- } \\
\text { Monitoring }\end{array}$ & Province of Alberta & On-going & 1 \\
\hline D.1 & Update Study & FISAA/Province/Consultant & $\begin{array}{l}\text { Every Three } \\
\text { Years }\end{array}$ & 2 \\
\hline
\end{tabular}


PT\#41-95/[FISAAIREPORT.DOC] 
APPENDIX A

SURVEY QUESTIONNAIRE 


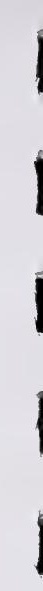




\section{QUESTIONNAIRE \\ FOREST INDUSTRY SUPPLIERS SECTOR STUDY}

Company Name:

Address:
Telephone (403)

Fax (403)

Is your organization currently a member of the Forest Industry Suppliers Association of Alberta (FISAA)? Yes No

\section{Number of Employees and Corporate Information}

a) How many people does your organization employ in Alberta (based on full time equivalent positions)?

b) Where is your organization's head office located?

c) Do you have regional offices in Alberta? Yes No If yes, please check the location of your major offices which supply the forest industry:

\begin{tabular}{|c|c|c|c|c|}
\hline Athabasca & - & Fort McMurray & - & Pincher Creek \\
\hline Barrhead & & Grande Prairie & & Red Deer \\
\hline Calgary & & High Prairie & & Rocky Mountain House \\
\hline Drayton Valley & - & High Level & - & Slave Lake \\
\hline Edson & - & Hinton & - & Whitecourt/Mayerthorpe \\
\hline Edmonton & - & Peace River & - & Other \\
\hline
\end{tabular}

d) For how many years has your company supplied Alberta's forest industry? years

\section{Supplies to the Forest Industry}

Please indicate the primary category (or categories) of services or products that your organization supplies to the forest industry. If you provide more than one category of services or products, please indicate the percentage of your business in each category.

Forest services (e.g. tree planting, firefighting and timber cruising)

Manufacturing products (e.g. making chemicals, valves, conveyor belts and equipment)

Construction (e.g. construction project management, equipment rental with operator, road building, heating systems)

Transportation, communication, utilities (e.g. trucking, telephone lines, power)

Wholesale trade (e.g. distributing products such as fuel, chemicals, machinery and valves)

Business services (e.g. providing engineering and technical services, accounting, legal, advertising)

General services (e.g. repair, maintenance, travel, equipment leasing without operator)

Other (government, membership organizations, herbicide sprayers, employment agencies) 
Please specify the products or services you supply to the forest industry

\section{Discussion of Economic Opportunities}

a) Describe limiting factors, in order of significance, which prevent your company from expanding its supply to the forest industry:

1.

2.

3.

Other

b) In order of significance, which measures would promote your growth in the forest industry?

1.

2.

3.

Other:

c) Of those sectors which are NOT customers, which do you believe you may move into (in Alberta) during the next five years?

\section{Logging/woodlands}

Pulp and paper

Lumber

Panel board (e.g. OSB, particle board and MDF)

Engineered building products (including pre-fab buildings)

Wood manufacturing (e.g. cabinets, window frames)

Paper converters and packaging

d) What could an industry organization such as FISAA do to help improve economic opportunities for your industry? 
4. . Financial Profile (note: Specific figures will remain confidential to SENTAR Consultants

Ltd. Figures will be published in an aggregated form only)

a) What was your organization's gross revenue in the last fiscal year?

What was the percentage of gross revenue from Alberta customers?

$\$$

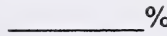

Of your revenue from Alberta customers, what percentage resulted from supply of

materials and/or services to customers in: Forest Industry

Oil and Gas Industry

$\%$

Other

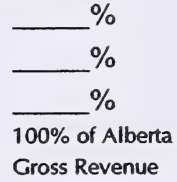

b) Which Alberta forest sectors represent your customers (check one or more)?

Logging/woodlands

_ Pulp and paper

Lumber

_ Panel board (e.g. OSB, particle board and MDF)

__ Engineered building products (including pre-fab buildings)

- Wood manufacturing (e.g. cabinets, window frames)

Paper converters and packaging

c) What percentage of your organization's gross revenue can be attributed to forest industry customers in:

Saskatchewan _ $\%$ British Columbia _ $\%$

Other Provinces __ \% United States_ _ _ $\%$

Overseas _ $\%$

\section{5. . . Follow-up Discussion}

During the next four years it is projected that \$3-4 billion will be spent on capital construction in Alberta's forest industries. To maximize the benefits to Alberta companies, Alberta Economic Development and Tourism and the Forest Industry Suppliers Association of Alberta are sponsoring a workshop on July 27, 1995 at the Mayfield Inn in Edmonton. The meeting will focus on:

- presenting the results from this survey; and

- exploring further industry strategies to reduce or illuminate limiting factors and to maximize the opportunities for growth.

Are you interested in attending this workshop in Edmonton? Yes No If yes, we will provide you with additional information.

Completed by: Name: Position:

Thank you for your time.

$\Rightarrow$ Please fax this survey before June 26, 1995 to: SENTAR Consultants Ltd., FAX (403) 420-0622

10160 - 112 Street Edmonton, Alberta T5K 2L6

Telephone: (403) 428-0003 


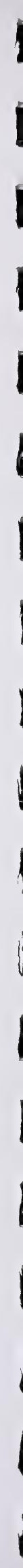


APPENDIX B

LISTS OF SURVEY RESPONDENTS AND WORKSHOP PARTICIPANTS 
Survey Responders and Workshop Attendees - FISAA Members (in Alberta, unless otherwise indicated)

A.R. Williams Materials Handling Ltd.

AGRA Earth \& Environmental

Alberta Freight Assembly Ltd.

Alberta Power Limited *

Alberta Research Counsel

Alberta Serv. Technologies

Anderson/CP Rubber

Anixter Inc.

Armtec

B.J. Electric Supplies

Baldor Motors \& Drives

Bantrel Inc. *

Bearing Supply

Belzil Computer Services

Berendsen Fluid Power

Borden-Nar (Canada)

Brian Alexander

Cadillac Plastic

Camsteel Fabricators

Canron Construction *

Canspec Group Inc.

Cantech Corp.

Capital Coatings

Century Sales \& Service Ltd.

Cessco Fabrication \& Engineering *

Chemco Electrical Contractos Ltd.

Chemex Labs Alberta Inc. *

Clark Builders

$\mathrm{CN}$

Continental LIme

Coopers \& Lybrand

Cormode \& Dickson Construction Ltd. *

Creative Concepts

Dacro Industries Ltd:

Desco Coatings of $A B$

Dominion Bridge Inc.

Dow Chemical Canada Ind

Dupont Canada

Empire Iron Works

Enviro-Test Laboratories

Eskimo Steel Ltd.

Flexxaire Mfg. Inc.

Fluid Treatment Technologies

Foxboro Canada Inc.

Gateway Refr.

GKO Design Consultants Inc.

GLM Tanks \& Equipment *

Goodyear Canada Inc. *

Grinnell Fire Protection

Hydra-Group Ltd.

Ian Murray \& Associates *

* Participated in July 27, 1995 Workshop
Edmonton

Calgary

Calgary

Edmonton

Edmonton

Edmonton

Edmonton

Edmonton

Edmonton

Edmonton

Edmonton

Edmonton

Calgary

Edmonton

Peace River

Edmonton

Edmonton

Edmonton

Edmonton

Edmonton

Edmonton

Edmonton

Edmonton

Edmonton

Edmonton

Edmonton

Edmonton

Edmonton

Edmonton

Calgary

Edmonton

Edmonton

Edmonton

Edmonton

Edmonton

Calgary

Didsbury

Burnaby, BC

Edmonton

Edmonton

Edmonton

Edmonton

Bonnyville

Edmonton

Edmonton

Edmonton

Nisku

St. Albert

Edmonton

Edmonton

Edmonton
IGL Canada Ltd.

Edmonton

IMAC Design Group Ltd. *

Image Commercial Uniforms Co. Ltd.

Edmonton

Edmonton

Industra Service Corp., Canadian Energy Service Edmonton

Industrial Equipment Co. Ltd. *

Klohn-Crippen Consultants Ltd.

Edmonton

Lafarge Precast

Makloc Buildings

Marsulex Inc,

Maryn Lubricants Inc.

Media Match Communications

Meridian Specialities Inc.

Methanex Corp.

Neste Resins Canada

Noralta Metal Fabricators Inc. *

Norwesco Industries (1983) Ltd *.

Norwood Foundry

Nusco Mfg. \& supply Ltd.

Pacfor Equipment Inc.

PCL Industrial Constructors Inc.

Pearson Timberline Forestry Consultants

Peter Morin Ent

Petro-Canada

Portal Crane Parts Ltd.

Premay Equipment Ltd.

Price Steel Ltd.

Pyramid Electric Corp.

Rault Consulting Services Inc. *

Redline Equipment Ltd. *

Riley's Reproduction Printing

Rosemount

Runners Express

Russel Metals

S.P.R.S.

Scona Electric Ltd.

Sherritt Inc.

Simonds Industries INC.

Simons-Stanley Joint Venture *

Simson-Maxwell

Spantec Constructors

Sterling Crane

Sueans Eng. AB Ltd.

Thurber Engineering

Transalta Utilities

UMA Engineering Ltd. *

Van Waters \& Rogers

Vicom Multimedia *

Wainbee Ltd. *

Weldco-Beales Mfg. Ltd.

Western Materials Handling \& Equipment

Westlund Ind. Supply

Zep Alcare *
Calgary

Edmonton

Nisku

Fort Sask.

Calgary

Edmonton

Edmonton

Calgary

Edmonton

Edmonton

Edmonton

Nisku

Nisku

Grande Prairie

Edmonton

Edmonton

Edmonton

Calgary

Coquitlam, BC

Edmonton

Edmonton

Nisku

Edmonton

Edmonton

Edmonton

Edmonton

Edmonton

Edmonton

Edmonton

Edmonton

Redwater

Delta, BC

Edmonton

Edmonton

Edmonton

Edmonton

Edmonton

Edmonton

St. Albert

Edmonton

Edmonton

Edmonton

Edmonton

Edmonton

Edmonton

Edmonton

Edmonton 
Survey Responders and Workshop Attendees - Non-FISAA Members (in Alberta, unless otherwise indicated)

Albchem Industries

Alberta Chain \& Rigging

Alfit Fastners

Anderson Water Systems Ltd.

Arrow West Equipment Ltd. *

Aspen Hydraulics Ltd.

BC Bearing Engineers Ltd.

BPS Bindery Rentals Ltd.

BTS Byers Transportation *

Butler Survey Supplies Ltd. *

Canadian Timken Limited

Clear Lake Ltd.

CXY Chemicals

Davco Machine Ltd.

Digital Equipment of Canada

Dow Corning Canada Inc.

Edmonton Saw Service Ltd.

EnviResource Consulting Ltd.

Forest Lease Inc.

Forestech Enterprises Ltd.

ForestPro Consulting

Grimshaw Trucking and Distributing Ltd.

Hammer Equipment Sales

HMW Construction Lid.

Intertape Polymer

ISECO Safety Shoes

Lemax Machine

McCay Bros.

McKay's Rotating Equipment Services

Miero Industries (Alberta) Ltd.

Norman Wade Company Limited

Northern Belting Co. Ltd.

Norwest Labs

Oliver Industrial Supply

Polymer Science Corp.

Princeton Carbide SErvice Ltd.

Provy Sales/Arc Machines

PRT Alberta Inc.

Regent Industries

Safeway Consulting Services Ltd.

Steel Industries Ltd.

Sterling Pulp Chemicals Ltd.

The Forestry Corp.

Tracksall ind. Ltd.

Twin Tractor, A Div. of Brandt Tractor

Woodline Products Ltd
Bruderheim

Edmonton

Edmonton

Dundas, ON

Spruce Grove

Rocky Mountain House

Red Deer

Edmonton

Edmonton

Edmonton

Nisku

Edmonton

Bruderheim

Grande Prairie

Edmonton

Calgary

Edmonton

Calgary

Spruce Grove

Edmonton

Peace River

Edmonton

Spruce Grove

Edmonton

Innisfail

Edmonton

Fort McMurray

Edmonton

Fort McMurray

Edmonton

Edmonton

Grande Prairie

Edmonton

Calgary

Calgary

Grande Prairie

Edmonton

Beaverlodge

Edmonton

Whitecourt

Grande Prairie

Grande Prairie

Edmonton

Whitecourt

Red Deer

Edmonton

* Participated in July 27, 1995 Workshop

Note: Additional workshop attendees were Alberta Economic Development \& Tourism and the Forest Industry Suppliers Association of Alberta 
APPENDIX C

"PARKING LOT" OF WORKSHOP POINTS REQUIRING FURTHER DISCUSSION 



\section{Workshop Proceedings \\ Forest Industry Supply Sector Workshop}

\section{PARKING LOT}

\section{DATABASE}

Many groups suggested that FISAA operate a database, but the structure and function of the database was not decided at the workshop. Groups suggested the following foci to the database:

- $\quad$ a database with only the names of forest producers and consulting engineering companies for use by FISAA members;

- $\quad$ a database of FISAA members for use by forest producers.

Groups agreed that the database should be designed with the users in mind; users should be contacted and asked what they would use, and how it would be of most use to them. The database must also be credible, not referring too many suppliers. Groups also agreed that once the database is complete, that its intended users should be taught to use it efficiently and effectively.

Toward the end of the session, several participants expressed concerns regarding the cost and utility of a database as well as confidentiality issues regarding a database.

\section{EDUCATION}

Several groups also stressed the importance of education. The format for educational activities suggested ranged from luncheon seminars, to night classes or one or two day seminars. The topics to be addressed also varied, with some groups stressing an overview of processes or more detailed information on processes, while others stressed the importance of understanding terminology.

\section{TERMINOLOGY}

Most groups expressed a need for improved knowledge of terminology. Some people indicated that they would appreciate a course on terminology, while others suggested that FISAA should prepare a glossary book. One participant recommended that people should read an existing book entitled "A Glossary of Pulp and Paper Terms". 


\section{RESOURCE LIBRARY}

Two groups suggested that FISAA could operate a lending library or resource room with information and videos on mills. Some participants questioned whether it would be used enough to justify the expense of acquiring materials and monitoring lending.

\section{"BETTER BUY ALBERTA" PROGRAMS}

Paul Short provided a brief overview of Alberta Economic Development and Tourism's role in promoting Alberta purchasing by mills. The Alberta Industrial Benefits Strategy program, which encourages mills to purchase locally and monitors their purchasing at irregular intervals, is not legislated, but endorsed by cabinet. Paul Short recommended that suppliers who are interested in this program should contact Mr. Brad Trefan, Director, Procurement Development, Alberta Economic Development \& Tourism, for more information.

Participants agreed that "Alberta First" programs were of value, but must be handled carefully to avoid being protectionist. The perception of protectionism could limit Alberta suppliers' opportunities for exporting goods and services outside the province.

\section{FISAA's ROLE}

Some participants indicated that some of the actions suggested during the afternoon session extended well beyond FISAA's existing mandate.

There was also some discussion about whether FISAA should provide services to members only or whether their mandate should be expanded to cover nonmembers.

\section{EFFECTIVE MARKETING}

Some participants were concerned that forest producers would not use a directory or a database of forest industry suppliers because they were deluged with information already. Forest producers are working toward partnerships with industry rather than extended bid lists. These participants indicated we should examine more closely what forest producers want from suppliers. 


\section{THE ENVIRONMENTAL SERVICES ASSOCIATION OF ALBERTA (ESAA)}

With interest in databases and education stressed throughout the afternoon session, it was brought to the group's attention that an association with a similar mission had already undertaken many similar initiatives. Trevor Reay described some of the services provided by ESAA. 

APPENDIX D

DEFINITION OF CATEGORIES 



\section{DEFINITION OF CATEGORIES}

(From Figures 28 - 33)

Supplier Marketing - relates to the following general themes:

- improved knowledge of client base

- $\quad$ contact names (at client facilities)

- client education/awareness

- $\quad$ "buy Alberta" or "buy locally" marketing promotions

- $\quad$ FISAA's role in marketing

- $\quad$ promotion/exposure

- $\quad$ networking opportunities

Client Purchasing - relates to the following themes:

- $\quad$ producers do not recognize local suppliers' abilities

- client purchasing habits/preferences

- location of suppliers from mills

Supply Industry Human Resources and Experience - relates to the following theme:

- $\quad$ qualified (knowledge and experience) sales staff

Product Synergy - relates to the following theme:

- $\quad$ nature of the product or service (e.g. product range limitations; product or service needed only during certain phases of mill operations)

Other Issues- relates to the following themes:

- legislative, regulatory and policy issues

- competition issues

- taxes/costs

- length of contracts

- maintaining, servicing and backing up products/services 
APPENDIX E

BIBLIOGRAPHY 



\section{Bibliography}

Alberta Economic Development and Trade. Forest Industry Development Study. 1990. Edmonton, Alberta. IMC Consulting Group Inc.

Alberta Economic Development and Tourism. A Review of the Economic Impact of the Forest Industry in Alberta. 1994. Price Waterhouse.

Canada-Alberta Partnership Agreement in Forestry. A Study of the Economic Importance of the Forest Sector in Alberta. 1994. Edmonton, Alberta. Ernst \& Young.

Canada-Alberta Partnership Agreement in Forestry. Directory of Primary Wood-Using Industries in Alberta. 1992. Edmonton, Alberta.

Canada-Alberta Partnership Agreement in Forestry. Directory of Secondary Wood-Using Industries in Alberta. 1992. Edmonton, Alberta.

Forest Industry Suppliers Association of Alberta. 1994 Membership Directory \& Buyers Guide. 1994. Edmonton, Alberta.

Statistics Canada. Standard Industrial Classification. 1980. Ottawa, Ontario.

Technical Association of the Pulp and Paper Industry. TAPPI Notes: Marketing to the Pulp and Paper Seminar. 1989. Atlanta, Georgia. 

National Library of Canada Bibliothèque nationale du Canada 